\title{
Effect of pre-oxidation on the oxidation resistance of Crofer 22 APU
}

\author{
Talic, Belma; Molin, Sebastian; Hendriksen, Peter Vang; Lein, Hilde Lea
}

\section{Published in:}

Corrosion Science

Link to article, DOI:

10.1016/j.corsci.2018.04.016

Publication date:

2018

Document Version

Peer reviewed version

Link back to DTU Orbit

Citation (APA):

Talic, B., Molin, S., Hendriksen, P. V., \& Lein, H. L. (2018). Effect of pre-oxidation on the oxidation resistance of Crofer 22 APU. Corrosion Science, 138, 189-199. https://doi.org/10.1016/j.corsci.2018.04.016

\section{General rights}

Copyright and moral rights for the publications made accessible in the public portal are retained by the authors and/or other copyright owners and it is a condition of accessing publications that users recognise and abide by the legal requirements associated with these rights.

- Users may download and print one copy of any publication from the public portal for the purpose of private study or research.

- You may not further distribute the material or use it for any profit-making activity or commercial gain

- You may freely distribute the URL identifying the publication in the public portal

If you believe that this document breaches copyright please contact us providing details, and we will remove access to the work immediately and investigate your claim 


\title{
Effect of pre-oxidation on the oxidation resistance of Crofer 22 APU
}

\author{
Belma Talic ${ }^{\mathrm{a}, \mathrm{b}}$, Sebastian Molin ${ }^{\mathrm{b}}$, Peter Vang Hendriksen ${ }^{\mathrm{b}}$, Hilde Lea Lein ${ }^{\mathrm{a}}$ \\ a Department of Materials Science and Engineering, Norwegian University of Science and Technology, \\ Norway \\ ${ }^{b}$ Department of Energy Conversion and Storage, Technical University of Denmark, Risø Campus, Denmark
}

\begin{abstract}
The ferritic stainless steel Crofer 22 APU is attractive for the use as interconnects in solid oxide fuel cell stacks. The oxidation rate of this alloy in air at $800{ }^{\circ} \mathrm{C}$ was reduced by pre-oxidation at higher temperatures in either air or $\mathrm{N}_{2}-9 \% \mathrm{H}_{2}-1 \% \mathrm{H}_{2} \mathrm{O}$. Conversely, the oxidation rate increased when the alloy grain size was increased by heat-treating in $\mathrm{H}_{2}\left(\mathrm{pO}_{2} \sim 10^{-21} \mathrm{~atm}\right)$. In all cases the scale formed on Crofer 22 APU consisted of an outer $(\mathrm{Mn}, \mathrm{Cr})_{3} \mathrm{O}_{4}$ layer, an inner $\mathrm{Cr}_{2} \mathrm{O}_{3}$ layer and sub-scale $\mathrm{MnCr}_{2} \mathrm{O}_{4}$ nodules that preferentially formed at alloy grain boundaries.
\end{abstract}

Keywords: stainless steel (A); SEM (B); high temperature corrosion (C); oxidation (C)

\section{Introduction}

Solid oxide fuel cells (SOFC) offer an environmentally friendly way of converting the chemical energy in fuels such as $\mathrm{H}_{2}, \mathrm{CO}$ or $\mathrm{CH}_{4}$ to electrical energy at a high electrical conversion efficiency [1]. A single SOFC unit consists of a dense, oxide ion conductive electrolyte sandwiched between two porous electrodes and has an open circuit potential of $\sim 1 \mathrm{~V}$ in typically used fuel mixtures [1]. To obtain higher voltages needed for practical applications several cells are stacked in series. Interconnects are then used between the electrodes of adjacent cells to provide a path for the current and separate the fuel supplied to one cell from the oxidant supplied to the other. In addition to being electrically conductive and stable in the fuel and oxidant atmospheres, the interconnect material should be chemically compatible with the electrode materials, have a thermal expansion coefficient matching the other SOFC components, easy to manufacture and shape, and affordable $[2,3]$.

Ferritic stainless steels (FSS) are promising for this application as they satisfy many of the above criteria [4,5]. In recent years, a number of new alloys such as Crofer 22 APU, Sanergy HT and Hitachi ZMG232 have been developed specifically for the application as the SOFC interconnect material [68]. These alloys have several common features such as: a high Cr-content (20-24 wt.\%) to ensure a 
large "Cr-reservoir" for long-term stability [9], minor additions of $\mathrm{Mn}(<1 \mathrm{wt} . \%)$ to form an outer $(\mathrm{Mn}, \mathrm{Cr})_{3} \mathrm{O}_{4}$ scale that reduces Cr-volatilization [10], and additions of reactive elements such as La or $\mathrm{Zr}$ for improved scale adherence and oxidation resistance [11,12]. However, using even these specialized FSS grades as the interconnect material in SOFC stacks presents some challenges.

The corrosion resistance of FSS relies on the formation of a $\mathrm{Cr}_{2} \mathrm{O}_{3}$ scale and the $\mathrm{Cr}$ concentration in the alloy decreases as this scale grows with time. For thin components or long operation times the $\mathrm{Cr}$ content may decrease beneath the critical level where breakaway oxidation occurs, which limits the interconnect lifetime [13]. Furthermore, the moderate electrical conductivity of $\mathrm{Cr}_{2} \mathrm{O}_{3}$ leads to an increase in the SOFC stack resistance as the oxide scale grows with time $[14,15]$. Another challenge is the volatilization of $\mathrm{Cr}(\mathrm{VI})$ species, which have been found to degrade the electrochemical performance of the oxygen electrode $[16,17]$. These adverse effects require that the FSS is coated in order to meet satisfactory service lifetimes [18].

$(\mathrm{Mn}, \mathrm{Co})_{3} \mathrm{O}_{4}$ spinels are promising coating materials that have been shown to reduce the FSS oxidation rate and limit Cr-volatilization [19-23]. We have previously [24] reported on the oxidation behaviour of $\mathrm{MnCo}_{1.7} \mathrm{Fe}_{0.3} \mathrm{O}_{4}$ coated Crofer $22 \mathrm{APU}$ in air at $800{ }^{\circ} \mathrm{C}$. The coating was deposited by electrophoretic deposition and heat-treated in either air or $\mathrm{N}_{2}-9 \% \mathrm{H}_{2}-1 \% \mathrm{H}_{2} \mathrm{O}$ at different temperatures, resulting in different coating densities. A porous coating (heat treated $2 \mathrm{~h}$ in air at $900{ }^{\circ} \mathrm{C}$ ) reduced the parabolic oxidation rate of Crofer 22 APU by a factor of 3 , while a more dense coating (heat treated $5 \mathrm{~h}$ at $1100{ }^{\circ} \mathrm{C}$ in $\mathrm{N}_{2}-9 \% \mathrm{H}_{2}-1 \% \mathrm{H}_{2} \mathrm{O}$ and $5 \mathrm{~h}$ at $800{ }^{\circ} \mathrm{C}$ in air) reduced the oxidation rate of Crofer $22 \mathrm{APU}$ by a factor of 10 . The difference in oxidation resistance was postulated to be mainly an effect of the difference in coating density, however, the influence of alloy pre-oxidation could not be excluded, i.e. the observed difference could in principle be an effect of the pre-treatment.

Magdefrau et al. [25] showed that the parabolic oxidation rate of Crofer $22 \mathrm{APU}$ in air at $800^{\circ} \mathrm{C}$ could be reduced by a factor of 3.5 by heat treatment in $\mathrm{Ar}$ at $1050^{\circ} \mathrm{C}$ for $4 \mathrm{~h}$, which increased the alloy grain size from ca. 16 to $250 \mu \mathrm{m}$. The beneficial effect of this heat treatment was attributed to an increased proportion and grain size of the $\mathrm{MnCr}_{2} \mathrm{O}_{4}$ layer formed on top of the $\mathrm{Cr}_{2} \mathrm{O}_{3}$ scale. Others have reported that pre-oxidation of Crofer $22 \mathrm{APU}$ in air is beneficial for improving the oxidation resistance during subsequent exposure to $\mathrm{H}_{2}-\mathrm{H}_{2} \mathrm{O}$ [26]. Also , pre-oxidation in $\mathrm{H}_{2}-\mathrm{H}_{2} \mathrm{O}$ was found beneficial for reducing erosion-corrosion of Incoloy $800 \mathrm{H}$ in air at $500{ }^{\circ} \mathrm{C}$ with silica as the erodent [27]. The influence of pre-oxidation on $\mathrm{Cr}$ volatilization was studied by Wongpromrat et al. [28]. Literature on the effect of pre-oxidation of chromia forming alloys is otherwise limited.

In this work, we investigate the effect of pre-oxidation on the oxidation resistance of Crofer $22 \mathrm{APU}$ in air. The conditions for pre-oxidation were chosen based on the heat treatment procedures previously used in [24] to densify protective spinel coatings. This is to clarify whether some of the variation in oxidation rate with coating density should be attributed (fully or in part) to modifications of the alloy or thermally grown oxide scale, rather than to the direct effect of the coating. Additionally, samples where Crofer 22 APU was heat treated to increase the alloy grain size without forming an external oxide 
scale were included to investigate whether the change in oxidation resistance could be ascribed to an increase of the alloy grain size [25].

\section{Materials and methods}

A $1 \mathrm{~mm}$ thick sheet of Crofer 22 APU (Thyssen Krupp) with the composition given in Table 1 was used for this study. This batch belongs to the newer batches of Crofer 22 APU, with low Si and Al contents. The sheet was cut into $20 \times 20 \mathrm{~mm}$ coupons and a $3 \mathrm{~mm}$ hole was drilled in one of the corners to allow for hanging in the oxidation furnace. The coupons were ground with SiC-paper, polished down to $1 \mu \mathrm{m}$ using diamond abrasive and cleaned in acetone and ethanol for 10 minutes each in an ultrasonic bath. Typical thickness after polishing was $0.8-0.9 \mathrm{~mm}$.

Table 1. Composition of Crofer 22 APU alloy used in this study in wt.\%. Analysed by Optical Emission Spectroscopy (OES) at Force Technology, Denmark.

\begin{tabular}{ccccccccc}
\hline Alloy & $\mathrm{Fe}$ & $\mathrm{Cr}$ & $\mathrm{Mn}$ & $\mathrm{Ti}$ & $\mathrm{La}$ & $\mathrm{C}$ & $\mathrm{Si}$ & $\mathrm{Al}$ \\
\hline Crofer 22 APU & Bal. & 23 & 0.42 & 0.068 & $0.04-0.20^{1}$ & 0.003 & $0.049^{2}$ & 0.007
\end{tabular}

${ }^{1} \mathrm{La}$ was not analysed by OES. Concentration is according to manufacturer's datasheet

${ }^{2}$ Determination of Si content by OES is associated with large uncertainty

The coupons were heat treated to either grow an oxide layer and/or increase the grain size of the alloy. The pre-oxidation heat treatments were chosen based on the heat treatment procedures previously used in [24] to densify spinel coatings on Crofer 22 APU. Some coupons were also left in the polished state to serve as a reference, from here on referred to as the "as-received" samples. An overview of the preoxidation heat treatment procedures and sample abbreviations used throughout this text is given in Table 2. All heat treatments were performed in tubular furnaces with the coupons suspended vertically (hanging from an alumina rod) and with heating and cooling rates of $120{ }^{\circ} \mathrm{C} / \mathrm{h}$. Air and $\mathrm{N}_{2}-9 \% \mathrm{H}_{2}$ were bubbled through water at $5{ }^{\circ} \mathrm{C}$ to achieve a water vapour content of ca. $1 \%$. During heat treatment in $\mathrm{H}_{2}$, the furnace tube was (for safety reasons) initially purged with $\mathrm{Ar}$ and heated to $50{ }^{\circ} \mathrm{C}$ for $3 \mathrm{~min}$ before pure $\mathrm{H}_{2}$ was introduced. The gas was switched to Ar during cooling below $425{ }^{\circ} \mathrm{C}$. The flow rate of both gasses was $13 \mathrm{~L} / \mathrm{min}$. The $\mathrm{pO}_{2}$ in the furnace at $1100{ }^{\circ} \mathrm{C}$ was ca. $10^{-21}$ atm (measured by a zirconia sensor). The H1100 samples were re-polished before further oxidation.

Oxidation behaviour of the as-received and pre-oxidized samples was studied in stagnant air at $700{ }^{\circ} \mathrm{C}, 800^{\circ} \mathrm{C}$ and $900^{\circ} \mathrm{C}$. Three to five coupons of each type were suspended vertically in a chamber furnace (hanging from an alumina rod). Every $250 \mathrm{~h}$, the furnace was cooled to room temperature $\left(180{ }^{\circ} \mathrm{C} / \mathrm{h}\right)$ and the coupons were weight on a scale with $0.00001 \mathrm{~g}$ accuracy (XS205 Mettler Toledo). 
Surface structural characterization was performed on a Bruker D8 X-ray diffractometer (XRD) with $\mathrm{Cu} \mathrm{K} \alpha$ radiation. The diffractograms were collected on rotating samples from 15 to $75^{\circ} 2 \theta$ using a step size of $0.02^{\circ}$ and a collection time of $1 \mathrm{~s}$ per step.

Microstructural characterization was made using a Zeiss Supra 35 Field Emission scanning electron microscope (SEM) equipped with an energy dispersive X-ray spectroscopy detector (EDX, Noran System SIX X-ray microanalysis system). For cross sectional analysis the steel coupons were cold vacuum embedded in epoxy, ground and polished in successive steps down to $1 \mu \mathrm{m}$, and finally carbon coated. EDX data were collected at an acceleration voltage of $15 \mathrm{kV}$ and analysed using the Noran System SIX software (Thermo Scientific, ver. 2.3). Quantification of the collected spectra was performed by standardless analysis and the results are therefore semi-quantitative.

To reveal the alloy grains, epoxy mounted, polished samples were etched for $40 \mathrm{~s}$ by immersion in a mixture (by volume) of 1 part $\mathrm{HNO}_{3}, 3$ parts glycerol and 5 parts $\mathrm{HCl}$. The etched samples were inspected in an optical microscope (Leitz Aristomet) and the grain size was quantified by the linear intercept method on images of $1200 \times 900 \mu \mathrm{m}$. At least four lines on four representative images were analysed for each sample.

Table 2. Overview of heat treatment procedures and sample abbreviations used throughout this text.

\begin{tabular}{ll}
\hline Abbreviation & Pre-oxidation heat treatment \\
\hline As received & \\
O900 & $900{ }^{\circ} \mathrm{C}$, air- $1 \% \mathrm{H}_{2} \mathrm{O}, 2 \mathrm{~h}$ \\
$\mathrm{R} 900+\mathrm{O} 800$ & $900{ }^{\circ} \mathrm{C}, \mathrm{N}_{2}-9 \% \mathrm{H}_{2}-1 \% \mathrm{H}_{2} \mathrm{O}, 2 \mathrm{~h}+800{ }^{\circ} \mathrm{C}$, air- $1 \% \mathrm{H}_{2} \mathrm{O}, 2 \mathrm{~h}$ \\
$\mathrm{R} 1100+\mathrm{O} 800$ & $1100{ }^{\circ} \mathrm{C}, \mathrm{N}_{2}-9 \% \mathrm{H}_{2}-1 \% \mathrm{H}_{2} \mathrm{O}, 5 \mathrm{~h}+800{ }^{\circ} \mathrm{C}$, air- $1 \% \mathrm{H}_{2} \mathrm{O}, 5 \mathrm{~h}$ \\
R1100+O800-P & $\begin{array}{l}1100{ }^{\circ} \mathrm{C}, \mathrm{N}_{2}-9 \% \mathrm{H}_{2}-1 \% \mathrm{H}_{2} \mathrm{O}, 5 \mathrm{~h}+800{ }^{\circ} \mathrm{C}, \text { air- } 1 \% \mathrm{H}_{2} \mathrm{O}, 5 \mathrm{~h} \text {, polished after pre- } \\
\text { oxidation to remove the formed oxide scale }\end{array}$ \\
$\mathrm{H} 1100$ & $1100{ }^{\circ} \mathrm{C}, \mathrm{H}_{2}\left(\mathrm{pO}_{2} 10^{-21}\right.$ atm $), 2 \mathrm{~h}$, polished after heat treatment \\
\hline
\end{tabular}

\section{Results}

\subsection{Characterization after pre-oxidation}

XRD analysis of the sample surfaces after pre-oxidation heat treatment (see Table 2) is shown in Figure 1. The XRD for all of the samples shows an increasing background with increasing $2 \theta$ angle due to Fe fluorescence. The sample heat treated in pure $\mathrm{H}_{2}$ (H1100) has peaks belonging to the alloy only, identified as body centred cubic FeCr-alloy in the PDF-2 database. The surface of the H1100 sample had a metallic shine and no oxide scale was visible by SEM. Although no detectable oxide scale formed 
after the $\mathrm{H} 1100$ heat treatment, these samples were polished before further oxidation in air. This was done to introduce the same mechanical deformation to the surface as the "as-received" samples, which were also polished. XRD after the $\mathrm{O} 900$ (heated in air at $900{ }^{\circ} \mathrm{C}$ ) and $\mathrm{R} 900+\mathrm{O} 800$ heat treatments (heated in $\mathrm{H}_{2}-\mathrm{N}_{2}$ at $900{ }^{\circ} \mathrm{C}$, then in air at $800{ }^{\circ} \mathrm{C}$ ) shows peaks belonging to the alloy and a cubic spinel oxide, matching well with $\mathrm{MnCr}_{2} \mathrm{O}_{4}$ in the PDF-2 database. The relative intensity of the peaks belonging to the oxide are weaker for O900, reflecting formation of a thinner oxide scale. XRD of the $\mathrm{R} 1100+\mathrm{O} 800$ (heated in $\mathrm{H}_{2}-\mathrm{N}_{2}$ at $1100{ }^{\circ} \mathrm{C}$, then in air at $800{ }^{\circ} \mathrm{C}$ ) sample shows peaks belonging to $\mathrm{Cr}_{2} \mathrm{O}_{3}$ in addition to peaks belonging to the alloy and a cubic spinel oxide similar to the one observed on O900 and R900+O800 samples.

SEM backscatter electron (BSE) images of the R900+O800 sample after pre-oxidation are shown in Figure 2. The surface is mostly covered by an oxide scale of sub-micron (100-200 nm) sized grains. The cross sectional micrograph (Fig. $2 \mathrm{~b}$ ) shows a $0.3-0.8 \mu \mathrm{m}$ thick oxide scale containing significant amounts of $\mathrm{Fe}$ in addition to $\mathrm{Cr}$ and $\mathrm{Mn}$ according to EDX analysis. The $\mathrm{O} 900$ heat treatment leads to the formation of a 0.1-0.3 $\mu \mathrm{m}$ thick oxide scale with a composition as listed in Figure 2. The grain size of the oxide surface is similar that after the R900+O800 pre-oxidation.

SEM BSE images of the R1100+O800 sample after pre-oxidation are shown in Figure 3. The oxide scale has a plate and whisker-like morphology, characteristic for oxide scales formed in reducing atmospheres $[10,13,29]$. The cross sectional micrograph shows a $2.8-3.0 \mu \mathrm{m}$ thick oxide scale with some alloy inclusions. According to EDX analysis (not shown) the top and bottom part of the scale are rich in $\mathrm{Mn}$ and $\mathrm{Cr}$, while the central zone is practically pure $\mathrm{Cr}_{2} \mathrm{O}_{3}$. Internal Ti-rich oxides are visible in the near-scale areas of the alloy as darker contrast spots in the brighter contrast alloy. The brighter spot highlighted in Figure 3b is La-rich according to EDX. Such bright spots were observed in the alloy bulk of all samples. It should be noted that there was no indication of nitride formation after any of the heat treatments in $\mathrm{N}_{2}-9 \% \mathrm{H}_{2}$.

Optical micrographs of etched cross sections of as-received Crofer 22 APU and after the H1100 and R1100+O800 heat treatments are shown in Figure 4. The average grain size, determined by the linear intercept method, is $35 \mu \mathrm{m}$ for the as-received sample, $380 \mu \mathrm{m}$ for $\mathrm{H} 1100$ and $230 \mu \mathrm{m}$ for $\mathrm{R} 1100+\mathrm{O} 800$. Heat treatment for $2 \mathrm{~h}$ at $900{ }^{\circ} \mathrm{C}$ did not lead to any significant grain growth, i.e. the grain size after the $\mathrm{O} 900$ and $\mathrm{R} 900+\mathrm{O} 800$ heat treatments is the same as in the as-received alloy. As seen in Figure 4, the alloy grains in the R1100+O800 sample are smaller in the near-surface region of the sample compared to in the centre, while the grains of the H1100 sample are of more uniform size across the whole sample thickness. This is likely due to the formation of an oxide scale on the surface of R1100+O800, which inhibited grain-growth in the near-surface region of the alloy. The smaller grains in the near-surface region of the R1100+O800 sample account for the smaller average grain size, despite the longer heat treatment (5h) at $1100{ }^{\circ} \mathrm{C}$ compared to the $\mathrm{H} 1100$ sample $\left(2 \mathrm{~h}\right.$ at $\left.1100{ }^{\circ} \mathrm{C}\right)$. 


\subsection{Oxidation kinetics}

The average mass gain during pre-oxidation is $0.055 \mathrm{mg} / \mathrm{cm}^{2}$ for $0900,0.096 \mathrm{mg} / \mathrm{cm}^{2}$ for R900+O800, and $0.556 \mathrm{mg} / \mathrm{cm}^{2}$ for $\mathrm{R} 1100+\mathrm{O} 800$. The $\mathrm{H} 1100$ heat treatment results in an average mass loss of $0.024 \mathrm{mg} / \mathrm{cm}^{2}$. The mass change of all samples during subsequent oxidation in air at $800{ }^{\circ} \mathrm{C}$ is shown in Figure 5a. The mass gain during pre-oxidation has been added at $\mathrm{t}=0$ for the $\mathrm{O} 900, \mathrm{R} 900+\mathrm{O} 800$ and R1100+O800 samples, to emphasize that these samples had an oxide scale at the start of the aging test. The oxidation kinetics were evaluated using a double-logarithmic plot (log mass change versus log time; see Figures S1-S3 in Supplementary material). The slope of the double-logarithmic plot indicates what kind of power law type expression that would fit the weight gain curves the best [30]. The kinetics of the as-received, O900 and R900+O800 samples are in good agreement with a parabolic rate law:

$$
(\Delta m / A)^{2}=k_{P} t+C
$$

where $\Delta m / A$ is the mass change per unit area $\left[\mathrm{mg} / \mathrm{cm}^{2}\right], t$ is the time $[\mathrm{s}], k_{P}$ is the parabolic rate constant $\left[\mathrm{g}^{2} / \mathrm{cm}^{4} \mathrm{~s}\right]$ and $C$ is an integration constant. The parabolic rate constants were determined by a linear fit of the slope of a $(\Delta \mathrm{m} / \mathrm{A})^{2}$ versus $\mathrm{t}$ plot using the mass change measured between 250 and $1000 \mathrm{~h}$ oxidation. The parabolic rate constants are $4.2 \times 10^{-14} \mathrm{~g}^{2} / \mathrm{cm}^{4} \mathrm{~s}$ for the as-received sample, $2.5 \times 10^{-14} \mathrm{~g}^{2} / \mathrm{cm}^{4} \mathrm{~s}$ for $\mathrm{O} 900$ and $1.8 \times 10^{-14} \mathrm{~g}^{2} / \mathrm{cm}^{4} \mathrm{~s}$ for R900+O800. I.e. pre-oxidation in both air and $\mathrm{N}_{2^{-}}$ $9 \% \mathrm{H}_{2}-1 \% \mathrm{H}_{2} \mathrm{O}$ at $900{ }^{\circ} \mathrm{C}$ lower the oxidation rate of Crofer $22 \mathrm{APU}$ at $800{ }^{\circ} \mathrm{C}$ in air. It should be noted (cf. Fig. $5 \mathrm{a}$ and b) that the pre-treatment does in fact change the growth kinetics during the $800{ }^{\circ} \mathrm{C}$ aging test; the effect is stronger than just adding a certain scale during the pre-oxidation that impedes further corrosion in the subsequent aging period. If this was the only effect of the pre-oxidation, it should be possible to make the curves overlay in Fig. 5 a by shifting them on the time scale (That this is not possible is illustrated in Fig. S5 in the supplementary material).

The mass change of the R1100+O800 and $\mathrm{H} 1100$ samples deviates strongly from parabolic oxidation kinetics. The mass gain of the $\mathrm{R} 1100+\mathrm{O} 800$ samples is too low and irregular over the measured time for fitting to a rate equation. Nevertheless, from Figure 5 it is clear that the oxidation rate in the $1200 \mathrm{~h}$ following the $\mathrm{R} 1100+\mathrm{O} 800$ pre-oxidation is considerably decreased relative to the as-received sample. However, comparing the mass gain of the as-received and R1100+O800 samples in Figure 5a shows that the $\mathrm{R} 1100+\mathrm{O} 800$ pre-oxidation is equivalent to more than $1600 \mathrm{~h}$ aging at $800{ }^{\circ} \mathrm{C}$.

During the initial ca. $750 \mathrm{~h}$ of oxidation the mass gain of $\mathrm{H} 1100$ is the same as the mass gain of the as-received samples, but with further aging $\mathrm{H} 1100$ has a higher oxidation rate. After $1000 \mathrm{~h}$ at $800{ }^{\circ} \mathrm{C}$ the average mass gain of the $\mathrm{H} 1100$ samples is $0.44 \pm 0.02 \mathrm{mg} / \mathrm{cm}^{2}$, while the average mass gain of the as-received samples is $0.38 \pm 0.03 \mathrm{mg} / \mathrm{cm}^{2}$. By fitting the mass change of $\mathrm{H} 1100$ to the general rate equation, $(\Delta m / A)^{m}=k_{m} t+C$, the coefficient $m$ was determined to ca. 1.4, which indicates oxidation kinetics intermediate between linear and parabolic [30] (see Figure S3 in the Supplementary material). Thus, increasing the grain size has a clear adverse effect on the oxidation kinetics of Crofer 22 APU in air at $800{ }^{\circ} \mathrm{C}$. To investigate whether the beneficial grain size effect reported by Magdefrau et al. [25] 
could be due to internal oxidation or depletion of Mn from the alloy, some of the R1100+O800 samples were re-polished after pre-oxidation to remove the formed oxide scale (sample R1100+O800-P). The average mass gain of these samples after $1000 \mathrm{~h}$ at $800{ }^{\circ} \mathrm{C}$ was $0.32 \pm 0.04 \mathrm{mg} / \mathrm{cm}^{2}$, which is smaller than for the as-received samples $\left(0.38 \pm 0.03 \mathrm{mg} / \mathrm{cm}^{2}\right)$ (see Figure S4 in the Supplementary material). This indicates that the beneficial effect of grain size reported by Magdefrau is probably due to $\mathrm{Mn}$ depletion or internal oxidation. This is discussed further in section 4.2.

The "instantaneous" apparent parabolic rate constant, calculated as the local slope of the $(\Delta \mathrm{m} / \mathrm{A})^{2}$ versus time data, is plotted in Figure 5b. It is emphasized that not all samples obeyed parabolic oxidation kinetics, as described above. Nevertheless, Figure 5b allows for comparing the change in oxidation behaviour with time for the different samples and indicates possible changes in the oxidation mechanism with time. The as-received, O900 and R900+O800 samples show similar behaviour with rate constants that increase marginally with time. The development in $\mathrm{k}_{\mathrm{p}}$ with time shows that the beneficial effect of the $\mathrm{O} 900$ and $\mathrm{R} 900+\mathrm{O} 800$ pre-oxidation treatments is maintained over the full aging period, i.e. the scales formed with the pre-treatment (O900 and R900+O800) or possible changes to the sub-scale steel matrix, leads to a stronger reduction in corrosion rate than would a pre-oxidation at 800 ${ }^{\circ} \mathrm{C}$. The apparent $\mathrm{k}_{\mathrm{P}}$ of the $\mathrm{H} 1100$ samples increases at a relatively faster rate, which further supports that the oxidation rate increases as the alloy grain size is increased. The apparent $\mathrm{k}_{\mathrm{P}}$ of the $\mathrm{R} 1100+\mathrm{O} 800$ samples shows considerable scatter, however, the trend appears to be that the rate constant is increasing with time. This indicates that with continued oxidation, as the sample is equilibrated to $800{ }^{\circ} \mathrm{C}$, the oxidation rate of the $\mathrm{R} 1100+0800$ samples may approach the oxidation rate of the 0900 and R900+O800 samples.

The oxidation rates (in air) of the as-received and R900+O800 samples were also investigated at $700{ }^{\circ} \mathrm{C}$ and $900{ }^{\circ} \mathrm{C}$. The mass change with time data are shown in Figure $6 \mathrm{a}$ and b, respectively. For the R900+O800 samples, the mass change was re-calculated to include the mass gain during preoxidation $\left(0.096 \mathrm{mg} / \mathrm{cm}^{2}\right)$ and the curves were shifted along the $\mathrm{x}$-axis to adjust for the "equivalent age" of the sample. The "equivalent age" is taken as the time the as-received Crofer 22 APU would have to be oxidized in air at the $700{ }^{\circ} \mathrm{C}$ or $900^{\circ} \mathrm{C}$ before acquiring the same mass gain as during the pre-oxidation heat treatment. After this re-calculation, the difference in the mass change of the asreceived and pre-oxidized samples is within one standard deviation, as seen in Figure 6. It should be noted that when the results for oxidation at $800{ }^{\circ} \mathrm{C}$ are corrected for the equivalent age, there is a clear difference between the as-received and pre-oxidized samples (Figure S5 in the Supplementary Material). I.e. the oxidation kinetics at $800{ }^{\circ} \mathrm{C}$ are indeed reduced by the pre-oxidation.

Parabolic oxidation kinetics are obeyed at both $700{ }^{\circ} \mathrm{C}$ and $900{ }^{\circ} \mathrm{C}$ with the rate constant equal to $1.8 \times 10^{-15} \mathrm{~g}^{2} / \mathrm{cm}^{4} \mathrm{~s}$ at $700{ }^{\circ} \mathrm{C}$ and $1.3 \times 10^{-12} \mathrm{~g}^{2} / \mathrm{cm}^{4} \mathrm{~s}$ at $900^{\circ} \mathrm{C}$ (calculated based on results for the asreceived samples). Fitting the parabolic rate constants measured at $700{ }^{\circ} \mathrm{C}, 800{ }^{\circ} \mathrm{C}$ and $900{ }^{\circ} \mathrm{C}$ to the Arrhenius equation $\left(k_{P}=k_{0} \exp \left(E_{A} / R T\right)\right)$ results in an activation energy of $310 \mathrm{~kJ} / \mathrm{mol}$. This is a little higher than previously reported by Palcut et al. [31] for the oxidation of Crofer 22 APU in air 
between $800{ }^{\circ} \mathrm{C}$ and $900{ }^{\circ} \mathrm{C}(252 \mathrm{~kJ} / \mathrm{mol})$. A possible explanation for these differences is small batch to batch variations in the steel. Another possibility is that the oxidation kinetics change a little within the investigated temperature interval $\left(700-900^{\circ} \mathrm{C}\right)$. In case of the FSS Sandvik HT, Skilbred et al. [7] reported that the activation energy is higher when evaluated between 700 and $1000{ }^{\circ} \mathrm{C}(396 \pm 33$ $\mathrm{kJ} / \mathrm{mol})$ than between 800 and $900^{\circ} \mathrm{C}(272 \pm 20 \mathrm{~kJ} / \mathrm{mol})$.

\subsection{Characterization after oxidation at $800{ }^{\circ} \mathrm{C}$}

$\mathrm{X}$-ray diffractograms of all samples after $1000 \mathrm{~h}$ oxidation at $800{ }^{\circ} \mathrm{C}$ in air are shown in Figure 7. Peaks identified as belonging to chromia, a cubic spinel and the alloy can be observed for all samples. The H1100 sample shows slightly stronger reflections for chromia compared to the other samples; otherwise, the differences between the different samples are minimal.

The morphology and composition of the oxide scale after $1000 \mathrm{~h}$ oxidation at $800{ }^{\circ} \mathrm{C}$ in air is similar for the as-received, O900 and R900+O800 samples. Figure 8a shows surface SEM micrographs of the as-received Crofer 22 APU after oxidation. The surface morphology is characterized by oxide ridges arranged in a pattern with a periodicity commensurate with the grain size of the alloy (cf. Fig. 4a). The high magnification insert shows oxide grains in the range of 200-300 nm. Slightly fewer ridges cover the surface of the R900+O800 samples (not shown).

A cross sectional SEM image of the as-received sample is shown in Figure 8b. The oxide scale appears dense and well adherent to the alloy. The average oxide scale thickness was $1.8 \pm 0.3 \mu \mathrm{m}$. The thickness of the scale measured on the $\mathrm{O} 900$ and $\mathrm{R} 900+\mathrm{O} 800$ samples was $1.7 \pm 0.4 \mu \mathrm{m}$ and $1.6 \pm 0.3 \mu \mathrm{m}$, respectively. Oxide nodules with a diameter of ca. 2-5 $\mu \mathrm{m}$ are observed protruding into the alloy at periodic intervals of ca. $20-40 \mu \mathrm{m}$. The scale above these nodules is buckled and slightly thicker than the scale a few $\mu \mathrm{m}$ away from the nodules. The distance between the oxide nodules corresponds well with the distance between the ridges observed on the sample surface (cf. Fig. 8a) and the alloy grain size $(35 \mu \mathrm{m})$. The insert in Figure $8 \mathrm{~b}$ shows an optical micrograph of the same sample after chemical etching, demonstrating that the oxide nodules are located on alloy grain boundaries.

Figure 9 shows compositional EDX maps of the oxide scale on the as-received sample, revealing that the nodules beneath the scale are rich in Mn and Cr. Quantitative EDX point analysis indicate a $\mathrm{Cr} / \mathrm{Mn}$ atomic ratio close to 2/1, suggesting the composition is close to $\mathrm{MnCr}_{2} \mathrm{O}_{4}$. The scale above these spinel nodules consists of an inner $\mathrm{Cr}_{2} \mathrm{O}_{3}$ layer and an outer $(\mathrm{Mn}, \mathrm{Cr})_{3} \mathrm{O}_{4}$ layer. The $\mathrm{Mn} / \mathrm{Cr}$ ratio in the outer $(\mathrm{Mn}, \mathrm{Cr})_{3} \mathrm{O}_{4}$ layer varied across the sample. Overall, the $\mathrm{Mn}$ fraction was smaller at the $\mathrm{Cr}_{2} \mathrm{O}_{3} /(\mathrm{Mn}, \mathrm{Cr})_{3} \mathrm{O}_{4}$ interface compared to at the interface with air. However, it should be noted that this variation could be an artefact of the EDX interaction volume. Smaller internal oxides rich in Ti can also be identified in the EDX map. These were observed in the 30-40 $\mu \mathrm{m}$ subsurface region of all samples after oxidation. 
Figure 10 shows SEM images of the surface and cross section of the H1100 sample after $1000 \mathrm{~h}$ oxidation at $800^{\circ} \mathrm{C}$ in air. The grain size of the surface oxide is approximately $200-400 \mathrm{~nm}$. Oxide ridges can again be observed on the surface however, the distance between these is clearly greater than the distance between the ridges on the as received sample (cf. Fig. 8a). Correspondingly, fewer oxide nodules protruding into the alloy are observed in the cross sectional image of the H1100 sample (Fig. 10b). Considering the larger grain size of this sample before oxidation (Fig. 4b), this further proves that the nodules primarily are formed at alloy grain boundaries. The average oxide scale thickness after $1000 \mathrm{~h}$ oxidation at $800^{\circ} \mathrm{C}$ in air was measured to $2.1 \pm 0.4 \mu \mathrm{m}$.

The composition of the oxide scale far away from the subscale nodules is different between the asreceived and the H1100 samples. EDX linescans of the two samples are shown in Figure 11. In both cases, the scale consist of an inner $\mathrm{Cr}_{2} \mathrm{O}_{3}$ layer and an outer $(\mathrm{Mn}, \mathrm{Cr})_{3} \mathrm{O}_{4}$ layer but the oxide scale formed on $\mathrm{H} 1100$ has a greater fraction of $\mathrm{Cr}_{2} \mathrm{O}_{3}$ than the as-received sample. This is in accordance with the XRD results (Fig. 7) showing relatively higher intensity for peaks belonging to $\mathrm{Cr}_{2} \mathrm{O}_{3}$ on the $\mathrm{H} 1100$ sample. For the as-received sample, it may be noted that the fraction of spinel is greater in this flat part of the scale compared to above the oxide nodules (cf. Fig. 9). Trace amounts $(<1 \mathrm{wt} . \%)$ of Fe are detected in the oxide scale of both samples.

Surface and cross sectional SEM images of the R1100+O800 sample after $1000 \mathrm{~h}$ oxidation at $800{ }^{\circ} \mathrm{C}$ in air are shown in Figure 12. In this case, the surface is without any distinct oxide ridges. The high magnification insert in Figure 12a shows a more faceted oxide scale compared to the as-received and H1100 samples, with grains in the range of $300-800 \mathrm{~nm}$. The average thickness of the oxide scale was measured to $2.91 \pm 0.3 \mu \mathrm{m}$. Very few oxide nodules protruding into the alloy were found along the length of the sample. Alloy inclusions can be observed in the centre of the scale. EDX mapping of the cross section (Fig. 13) shows that the oxide scale below these alloy inclusions consist of a nearly continuous layer of (Mn, Cr) $)_{3} \mathrm{O}_{4}$, with composition close to $\mathrm{MnCr}_{2} \mathrm{O}_{4}$ according to quantitative EDX analysis. The scale above the alloy inclusions consists of an inner $\mathrm{Cr}_{2} \mathrm{O}_{3}$ layer and an outer $(\mathrm{Mn}, \mathrm{Cr})_{3} \mathrm{O}_{4}$ layer. The $\mathrm{Mn}$ concentration in the $(\mathrm{Mn}, \mathrm{Cr})_{3} \mathrm{O}_{4}$ layer increases from the interface with $\mathrm{Cr}_{2} \mathrm{O}_{3}$ and outwards.

\section{Discussion}

\subsection{Effect of pre-oxidation}

The results show that the oxidation rate of Crofer $22 \mathrm{APU}$ at $800^{\circ} \mathrm{C}$ in air can be somewhat reduced by pre-oxidation above this temperature and that pre-oxidation in $\mathrm{N}_{2}-9 \% \mathrm{H}_{2}-1 \% \mathrm{H}_{2} \mathrm{O}$ leads to a slightly larger improvement in the oxidation resistance compared to pre-oxidation in air. Noteworthy, a heat treatment that increases the alloy grain size without forming an oxide scale has an adverse effect on the 
oxidation resistance. The composition and morphology of the thermally grown oxide scales is clearly influenced by the heat treatment procedure. Before discussing how this may have influenced the oxidation behaviour, the oxidation of as-received Crofer 22 APU will be addressed.

The mass gain of as-received Crofer 22 APU followed parabolic kinetics and the oxidation rate constant at $800{ }^{\circ} \mathrm{C}$ in air $\left(4.2 \times 10^{-14} \mathrm{~g}^{2} / \mathrm{cm}^{4} \mathrm{~s}\right)$ is in line with previously reported results $[13,25,31]$. Parabolic behaviour is typically interpreted as kinetics controlled by solid state diffusion through the growing oxide scale [30]. According to two-stage ${ }^{16} \mathrm{O} /{ }^{18} \mathrm{O}$ oxidation experiments on Crofer $22 \mathrm{APU}$ in air the oxide scale grows by predominantly outward diffusion of cations, with a minor contribution from inward diffusion of oxygen [32,33].

After $1000 \mathrm{~h}$ at $800{ }^{\circ} \mathrm{C}$ in air the scale on as-received Crofer $22 \mathrm{APU}$ comprises an inner $\mathrm{Cr}_{2} \mathrm{O}_{3}$ layer, an outer $(\mathrm{Mn}, \mathrm{Cr})_{3} \mathrm{O}_{4}$ layer, and "subscale" $\mathrm{MnCr}_{2} \mathrm{O}_{4}$ nodules. This morphology has been observed in a number of previous oxidation studies of Crofer 22 APU and similar ferritic stainless steels $[10,11,13,25,34,35]$. Thermodynamically, the presence of $\mathrm{MnCr}_{2} \mathrm{O}_{4}$ at the alloy/scale interface is to be expected. Gibbs energy for the formation of $\mathrm{MnO}$ is more negative than for the formation of $\mathrm{Cr}_{2} \mathrm{O}_{3}$, and $\mathrm{MnCr}_{2} \mathrm{O}_{4}$ is the most stable compound at elevated temperatures and at the low $\mathrm{pO}_{2}$ expected at the alloy/scale interface [36]. Nevertheless, the major portion of $(\mathrm{Mn}, \mathrm{Cr})_{3} \mathrm{O}_{4}$ spinel is typically observed to form at the scale/atmosphere interface. This observation has been explained by the high oxygen affinity of $\mathrm{Mn}^{2+}$ and the greater diffusivity of $\mathrm{Mn}^{2+}$ compared to $\mathrm{Cr}^{3+}$ in thermally grown chromia $[37,38]$. Stott et al. [39] predicted that the high oxygen affinity of $\mathrm{Mn}^{2+}$ would with time result in decomposition of any $(\mathrm{Mn}, \mathrm{Cr})_{3} \mathrm{O}_{4}$ initially present at the alloy/scale interface, unless $\mathrm{Mn}$ supply from the alloy is sustained. Here, the $1 \mathrm{~mm}$ thick sample with $0.42 \mathrm{wt} \% \mathrm{Mn}$ (Table 1) contains enough Mn to form a ca. $14 \mu \mathrm{m}$ thick $\mathrm{MnCr}_{2} \mathrm{O}_{4}$ layer. Thus, the alloy is not depleted of $\mathrm{Mn}$ after $1000 \mathrm{~h}$ oxidation at $800{ }^{\circ} \mathrm{C}$ and the $(\mathrm{Mn}, \mathrm{Cr})_{3} \mathrm{O}_{4}$ layer is expected to remain at the alloy/scale interface for a long period of oxidation at $800^{\circ} \mathrm{C}$.

The subscale spinel nodules were observed to form preferentially at the alloy grain boundaries, which indicates that grain boundaries are fast diffusion paths for Mn. Zhu et al. [40] estimated that the bulk diffusion coefficient of $\mathrm{Mn}$ is twice that of $\mathrm{Fe}$ and $\mathrm{Cr}$ in ferrite at $800{ }^{\circ} \mathrm{C}$ and hypothesized that the difference in diffusivity should be even greater along the grain boundaries. Thorning and Sridhar [41] suggested that fast transport of Mn to the alloy surface instead should be attributed to an initially higher concentration of $\mathrm{Mn}$ at the alloy grain boundaries. With increasing temperature the difference between grain boundary and bulk diffusion in the alloy should decrease, explaining why a more continuous layer of $(\mathrm{Mn}, \mathrm{Cr})_{3} \mathrm{O}_{4}$ is formed at the alloy/scale interface after the $\mathrm{R} 1100+\mathrm{O} 800$ heat treatment (see Figure 13) [42]. The continuous $(\mathrm{Mn}, \mathrm{Cr})_{3} \mathrm{O}_{4}$ layer at the alloy/scale interface is not believed to have a major influence on the oxidation rate as $\mathrm{MnCr}_{2} \mathrm{O}_{4}$ is considered to be less protective than $\mathrm{Cr}_{2} \mathrm{O}_{3}$ due to the faster cation diffusion in the former $[38,39,43]$.

The volume increase associated with formation of the subscale $\mathrm{MnCr}_{2} \mathrm{O}_{4}$ nodules will result in tensile stresses in the external scale, assuming the nodules form and grow continuously while the chromia scale 
grows [44]. This is evident by the buckling of the alloy and scale above the nodules (see Figure 9). Unless the tensile stresses can be alleviated by creep, the oxide scale will be prone to cracking [45]. Cracks in the scale expose fresh alloy surface to the oxidizing gas, which leads to an increase in the oxidation rate. No cracks were directly observed by inspection in SEM after oxidation, however, this could be due to rapid crack healing by formation of new oxide. This seems plausible when noting that the oxide scale in proximity of the nodules often is thicker and has a greater fraction of $\mathrm{Cr}_{2} \mathrm{O}_{3}$ compared to the scale some distance away from the nodules (compare Fig. 9 and 11). Fewer sub-scale nodules should accordingly lead to a lower oxidation rate, which in part may explain the beneficial effect of preoxidation. However, considering that the highest mass gain was measured for H1100, which formed fewer nodules than the as-received, $\mathrm{O} 900$ and R900+O800 samples, the higher mass gain near the subscale nodules is most likely a minor contributor to the overall oxidation rate.

The beneficial effect of pre-oxidation is more likely related to changes in the transport properties of the thermally grown $\mathrm{Cr}_{2} \mathrm{O}_{3}$ scale resulting from a modification of the grain size and/or the defect structure. Cation diffusivity along $\mathrm{Cr}_{2} \mathrm{O}_{3}$ grain boundaries is several orders of magnitude larger than the lattice diffusivity and the oxidation rate should therefore decrease as the grain size of the $\mathrm{Cr}_{2} \mathrm{O}_{3}$ scale is increased [38,46,47]. The grain size of $(\mathrm{Mn}, \mathrm{Cr})_{3} \mathrm{O}_{4}$ on the surface of the $\mathrm{R} 1100+\mathrm{O} 800$ sample (300$800 \mathrm{~nm}$ ) was larger than on the surface of the as-received sample (200-300 nm) after oxidation. Although the $\mathrm{Cr}_{2} \mathrm{O}_{3}$ grain size in the different samples could not be measured, it is reasonable to expect that also this was larger for the R1100+O800 sample because of the higher temperature heat treatment.

From previous work on ferritic stainless steels and Ni-based alloys, it is known that the oxide scale formed in $\mathrm{H}_{2}-\mathrm{H}_{2} \mathrm{O}$ is different from that formed in air $[27,31,48,49]$. The oxide scales formed in $\mathrm{H}_{2}-$ $\mathrm{H}_{2} \mathrm{O}$ are in these studies reported to be more adherent and have lower residual growth stresses. The oxidation atmosphere may also affect the defect chemistry of thermally grown chromia. Interstitially dissolved $\mathrm{H}$ in an $\mathrm{M}_{2} \mathrm{O}_{3}$ oxide would increase the concentration of metal vacancies and decrease the concentration of oxygen vacancies, leading to an increased transport of cations and decreased transport of oxygen [50,51]. This in turn influences the growth mechanism and growth rate of the oxide scale. Latu-Romain et al. [52,53] showed that a Ni-30Cr alloy oxidized at $10^{-10}$ or $10^{-5}$ atm $\mathrm{O}_{2}$ formed $\mathrm{Cr}_{2} \mathrm{O}_{3}$ with p-type character at the scale/atmosphere interface and n-type character at the scale/alloy interface, while $\mathrm{Cr}_{2} \mathrm{O}_{3}$ with exclusively n-type character was formed during oxidation at $10^{-14} \mathrm{~atm} \mathrm{O}_{2}$. If a modification of the defect chemistry is responsible for the improved oxidation resistance after heat treatment in $\mathrm{N}_{2}-9 \% \mathrm{H}_{2}-1 \% \mathrm{H}_{2} \mathrm{O}$, the effect should last only until the scale is equilibrated with air. The results here do not indicate that the beneficial effects of the $\mathrm{O} 900$ and $\mathrm{R} 900+\mathrm{O} 800$ pre-oxidation treatments are transient; however, the oxidation behaviour will need to be studied over longer time to confirm this. More detailed inspection of the oxide scale by transmission electron microscopy would also aid to elucidate the beneficial effect of pre-oxidation. 
The $\mathrm{R} 900+\mathrm{O} 800$ pre-oxidation heat treatment had no apparent effect on the oxidation resistance of Crofer $22 \mathrm{APU}$ in air at $700{ }^{\circ} \mathrm{C}$ and $900{ }^{\circ} \mathrm{C}$ (See Figure 6), in contrast to what was observed at $800{ }^{\circ} \mathrm{C}$. The reasons for this are not apparent.

\subsection{Effect of increasing the alloy grain size}

Increasing the alloy grain size in an atmosphere that does not lead to oxidation of the alloy was shown to increase the oxidation rate of Crofer $22 \mathrm{APU}$ in air at $800{ }^{\circ} \mathrm{C}$. After $1000 \mathrm{~h}$ at $800{ }^{\circ} \mathrm{C}$ the mass gain of the H1100 sample (grain size $380 \mu \mathrm{m}$ ) was $\sim 15 \%$ higher than the mass gain on the as-received samples (grain size $35 \mu \mathrm{m}$ ). This is expected, as the transition to selective oxidation of $\mathrm{Cr}$ is known to take place at lower $\mathrm{Cr}$ contents for alloys with a smaller grain size or for alloys that have been coldworked to induce dislocations in the subsurface [30,54]. The faster formation of a protective scale is attributed to the more rapid diffusion of $\mathrm{Cr}$ along alloy grain boundaries, dislocations and similar shortcircuit paths. The alloy grain size also has an influence on the mechanical properties, and may thereby affect the stresses between the oxide scale and the alloy. Generally, the net stress in a thermally grown $\mathrm{Cr}_{2} \mathrm{O}_{3}$ scale will be compressive, leading to, on average, a tensile stress in the metal substrate [30]. One way of relieving the generated stresses is by creep, which is more significant in the metal substrate than in the oxide scale [55]. The creep resistance increases will increasing grain size, which means that other mechanisms for stress relief, such as scale cracking and buckling might become more important $[56,57]$. This could be a contributing reason for the increased oxidation rate observed with increased alloy grain size.

The results obtained here are in contradiction with those presented by Magdefrau et al. [25], where the parabolic oxidation rate of Crofer $22 \mathrm{APU}$ in air at $800{ }^{\circ} \mathrm{C}$ was reduced by a factor of 3.5 by increasing the grain size of the alloy from ca. 16 to $250 \mu \mathrm{m}$. There, the grain size was increased by heattreating in $\mathrm{Ar}$ at $1050{ }^{\circ} \mathrm{C}$ for up to $4 \mathrm{~h}$. The $\mathrm{pO}_{2}$ in this atmosphere and the mass change during the heat treatment was not stated. However, the authors report the presence of internal Ti-oxide precipitates in the near-surface region of the alloy and that the samples were polished after the heat treatment. Normally, the $\mathrm{pO}_{2}$ in supplies of noble gasses such as $\mathrm{Ar}$ is in the range above $10 \mathrm{ppm}$, making it an oxidizing atmosphere. Based on this information, we suggest an alternative explanation for the reduced oxidation rate with increased grain size observed by Magdefrau et al. Assuming the $\mathrm{pO}_{2}$ during heat treatment was sufficiently high to oxidize $\mathrm{Mn}$, the heat treatment and subsequent sample polishing would essentially decrease the concentration of $\mathrm{Mn}$ in the alloy. From literature it is known that the oxidation rate of ferritic stainless steels decreases with decreasing concentration of $\mathrm{Mn}$ in the alloy $[58,59]$. This hypothesis is corroborated by the mass gain results for the R1100+O800-P samples, which were polished after pre-oxidation to remove the oxide scale. The mass gain of these samples after $1000 \mathrm{~h}$ at $800{ }^{\circ} \mathrm{C}\left(0.32 \mathrm{mg} / \mathrm{cm}^{2}\right)$ was slightly lower than measured for both the as-received $\left(0.38 \mathrm{mg} / \mathrm{cm}^{2}\right)$ and $\mathrm{H} 1100\left(0.44 \mathrm{mg} / \mathrm{cm}^{2}\right)$ samples. It should be mentioned that although the addition of $\mathrm{Mn}$ to the alloy 
leads to an increase in oxidation rate, the formation of an outer $(\mathrm{Mn}, \mathrm{Cr})_{3} \mathrm{O}_{4}$ scale is beneficial for reducing Cr-volatilization [10].

Oxidation kinetics intermediate between parabolic and linear suggests that growth of the oxide scale on H1100 is partially controlled by some interfacial reaction [30]. From the available results it is not clear what this reaction could be. Since the H1100 sample was heat treated in pure $\mathrm{H}_{2}$, a possible influence by dissolved hydrogen in the steel should be considered. Tveten et al. [60] showed that the initial oxidation rate of chromium at $900{ }^{\circ} \mathrm{C}$ in $\mathrm{O}_{2}$ is higher for samples containing hydrogen compared to samples where the hydrogen content was decreased by vacuum annealing. Analysis of ${ }^{18} \mathrm{O}$ depth profiles indicated that $\mathrm{Cr}$ diffusion was faster and $\mathrm{O}$ diffusion was slower in the $\mathrm{Cr}_{2} \mathrm{O}_{3}$ scale formed on samples containing more $\mathrm{H}$. This is consistent with changes in the $\mathrm{Cr}_{2} \mathrm{O}_{3}$ defect chemistry due to interstitially dissolved hydrogen, as discussed in Section 4.1.

\subsection{Comparison with spinel coated Crofer 22 APU}

In a previous paper [24] we reported on the oxidation behaviour of $\mathrm{MnCo}_{1.7} \mathrm{Fe}_{0.3} \mathrm{O}_{4}$ coated Crofer 22 APU, where the coating was heat treated in different ways producing coatings of different density. The heat treatment procedures were identical to those used here to pre-oxidize the uncoated alloy, i.e. O900, R900+O800 and R1100+O800. The coated samples all followed parabolic oxidation kinetics in air at $800^{\circ} \mathrm{C}$. The deduced rate constants from [24] are summarized in Table 3 .

Comparing the oxidation rate of coated and bare pre-oxidized Crofer 22 APU it is clear that the coating has a smaller influence on the oxidation kinetics than if the results are compared against Crofer 22 APU that has not been pre-oxidized. However, it should be stressed that these mass gain measurements have not been corrected for effects of $\mathrm{Cr}$ vaporization. In [24] it was shown that the $\mathrm{Cr}$ evaporation rate of Crofer $22 \mathrm{APU}$ in air- $3 \% \mathrm{H}_{2} \mathrm{O}$ at $800{ }^{\circ} \mathrm{C}$ was reduced by a factor of 10 by the $\mathrm{O} 900$ coating and by a factor of 30 by the R1100+O800 coating. Thus, the lower apparent mass gain of uncoated Crofer 22 APU must in part be attributed to a higher mass lost by Cr evaporation. The exact contribution from $\mathrm{Cr}$ evaporation cannot be accurately assessed due to the lack of data for the testing conditions used in this study (stagnant air and low $\mathrm{H}_{2} \mathrm{O}$ content).

Nevertheless, the results presented here show that a part of the reduction in oxidation rate observed when applying a protective coating and heat treating it (as done for example in Ref. [24]) may also be induced by the heat treatment (pre-oxidation) in absence of the coating. As discussed above, the beneficial effect of the pre-oxidation seems to lie in a combination of fewer sub-scale $\mathrm{MnCr}_{2} \mathrm{O}_{4}$ nodules and a change in the defect chemistry and/or grain size of the oxide scale formed at the higher temperature and in the reducing atmosphere experienced during the pre-oxidation step. This is an important finding to keep in mind when benchmarking different coating solutions utilizing different heat treatment procedures to fabricate or densify the coating on the alloy. 
Table 3. Parabolic rate constant for bare and $\mathrm{MnCo}_{1.7} \mathrm{Fe}_{0.3} \mathrm{O}_{4}$ coated Crofer 22 APU oxidized in air at $800{ }^{\circ} \mathrm{C}$ after different pre-oxidation heat treatments.

\begin{tabular}{lcc}
\hline & $\begin{array}{c}\text { Pre-oxidized Crofer 22 APU } \\
{\left[\mathrm{g}^{2} / \mathrm{cm}^{4} \mathrm{~s}^{1}\right]}\end{array}$ & $\begin{array}{c}\mathrm{MnCo}_{1.7} \mathrm{Fe}_{0.3} \mathrm{O}_{4} \text { coated } \\
{\left[\mathrm{g}^{2} / \mathrm{cm}^{4} \mathrm{~s}^{1}\right]}\end{array}$ \\
\hline As-received & $4.2 \times 10^{-14}$ & $\mathrm{~N} / \mathrm{A}$ \\
$\mathrm{O} 900$ & $2.5 \times 10^{-14}$ & $1.4 \times 10^{-14}$ \\
$\mathrm{R} 900+\mathrm{O} 800$ & $1.8 \times 10^{-14}$ & $1.3 \times 10^{-14}$ \\
$\mathrm{R} 1100+\mathrm{O} 800$ & $\mathrm{~N} / \mathrm{A}$ & $0.34 \times 10^{-14}$ \\
\hline
\end{tabular}

\section{Conclusions}

The oxidation rate of Crofer $22 \mathrm{APU}$ in air at $800^{\circ} \mathrm{C}$ was shown to be slightly reduced by pre-oxidation above this temperature. Pre-oxidation at $900{ }^{\circ} \mathrm{C}$ in $\mathrm{N}_{2}-\mathrm{H}_{2}$ resulted in a slightly larger improvement in the oxidation resistance than pre-oxidation in air. Whereas the overall weight gain (pre-oxidation + aging period) was highest for a sample pre-oxidized for $5 \mathrm{~h}$ in $\mathrm{N}_{2}-\mathrm{H}_{2}$ at $1100{ }^{\circ} \mathrm{C}$, this sample showed the smallest mass gain during the $1200 \mathrm{~h}$ aging period at $800{ }^{\circ} \mathrm{C}$. The $900{ }^{\circ} \mathrm{C}$ pre-oxidation treatment in $\mathrm{N}_{2}-\mathrm{H}_{2}(\mathrm{R} 900+\mathrm{O} 800)$ did not change the oxidation kinetics at $900{ }^{\circ} \mathrm{C}$ in air, as expected. More surprisingly, the beneficial effect of pre-oxidation observed during aging at $800{ }^{\circ} \mathrm{C}$, was not observed when aging at $700{ }^{\circ} \mathrm{C}$.

Heat-treating the alloy in pure $\mathrm{H}_{2}$ at $1100{ }^{\circ} \mathrm{C}\left(\mathrm{pO}_{2}\right.$ ca. $\left.10^{-21} \mathrm{~atm}\right)$ increased the alloy grain size from 35 to $380 \mu \mathrm{m}$ without forming an oxide scale. This heat treatment and the induced grain growth had a clear negative effect on the oxidation resistance of Crofer $22 \mathrm{APU}$ in air at $800^{\circ} \mathrm{C}$. Removing the oxide scale formed during pre-oxidation in $\mathrm{N}_{2}-9 \% \mathrm{H}_{2}-1 \% \mathrm{H}_{2} \mathrm{O}$ at $1100{ }^{\circ} \mathrm{C}$ resulted in an overall slightly lower oxidation rate in air at $800{ }^{\circ} \mathrm{C}$, due to preferential removal of $\mathrm{Mn}$ from the alloy.

The thermally grown oxide scale comprised $\mathrm{Cr}_{2} \mathrm{O}_{3}$ at the alloy/scale interface, $(\mathrm{Mn}, \mathrm{Cr})_{3} \mathrm{O}_{4}$ at the scale/atmosphere interface and subscale $\mathrm{MnCr}_{2} \mathrm{O}_{4}$ nodules that preferentially formed at alloy grain boundaries. The subscale nodules caused buckling of the alloy and oxide scale in their proximity. Samples oxidized in $\mathrm{N}_{2}-9 \% \mathrm{H}_{2}-1 \% \mathrm{H}_{2} \mathrm{O}$ for $5 \mathrm{~h}$ at $1100{ }^{\circ} \mathrm{C}$ formed a nearly continuous layer of $(\mathrm{Mn}, \mathrm{Cr})_{3} \mathrm{O}_{4}$ along the alloy/scale interface, resulting in less scale buckling.

\section{Funding}

Financial support from Innovation Fund Denmark through the project SYNFUEL (project no. 410600006B), and the Faculty of Natural Sciences at NTNU is acknowledged. 


\section{References}

[1] S.C. Singhal, Solid Oxide Fuel Cells: Past, Present and Future, in: J.T.S. Irvine, P. Connor (Eds.), Solid Oxide Fuels Cells Facts Fig., Springer London, 2013: pp. 1-23. doi:10.1007/978-14471-4456-4_1.

[2] J.W. Fergus, Metallic interconnects for solid oxide fuel cells, Mater. Sci. Eng. A. 397 (2005) 271-283. doi:10.1016/j.msea.2005.02.047.

[3] W.J. Quadakkers, J. Prion-Abellan, V. Shemet, L. Singheiser, Metallic interconnectors for solid oxide fuel cells - a review, Mater. High Temp. 20 (2003) 115-127.

[4] S. Linderoth, P.V. Hendriksen, M. Mogensen, N. Langvad, Investigations of metallic alloys for use as interconnects in solid oxide fuel cell stacks, J. Mater. Sci. 31 (1996) 5077-5082. doi:10.1007/BF00355908.

[5] P. Kofstad, R. Bredesen, High temperature corrosion in SOFC environments, Solid State Ion. 52 (1992) 69-75. doi:10.1016/0167-2738(92)90092-4.

[6] R. Hojda, W. Heimann, W.J. Quadakkers, Production-capable materials concept for hightemperature fuel cells, ThyssenKrupp Techforum. (2003). http://cat.inist.fr/?aModele=afficheN\&cpsidt=15628707 (accessed April 10, 2016).

[7] A.W.B. Skilbred, R. Haugsrud, Sandvik Sanergy HT - A potential interconnect material for $\mathrm{LaNbO}_{4}$-based proton ceramic fuel cells, J. Power Sources. 206 (2012) 70-76. doi:10.1016/j.jpowsour.2012.01.101.

[8] T. Uehara, N. Yasuda, T. Ohno, A. Toji, Improvement of Oxidation Resistance of Fe-Cr Ferritic Alloy Sheets for SOFC Interconnects, Electrochemistry. 77 (2009) 131-133. doi:10.5796/electrochemistry.77.131.

[9] P. Huczkowski, V. Shemet, J. Piron-Abellan, L. Singheiser, W.J. Quadakkers, N. Christiansen, Oxidation limited life times of chromia forming ferritic steels, Mater. Corros. 55 (2004) 825830. doi:10.1002/maco.200303798.

[10] M. Stanislowski, E. Wessel, K. Hilpert, T. Markus, L. Singheiser, Chromium Vaporization from High-Temperature Alloys I. Chromia-Forming Steels and the Influence of Outer Oxide Layers, J. Electrochem. Soc. 154 (2007) A295-A306. doi:10.1149/1.2434690.

[11] D.E. Alman, P.D. Jablonski, Effect of minor elements and a Ce surface treatment on the oxidation behavior of an $\mathrm{Fe}-22 \mathrm{Cr}-0.5 \mathrm{Mn}$ (Crofer $22 \mathrm{APU}$ ) ferritic stainless steel, Int. J. Hydrog. Energy. 32 (2007) 3743-3753. doi:10.1016/j.ijhydene.2006.08.032.

[12] P.Y. Hou, J. Stringer, The effect of reactive element additions on the selective oxidation, growth and adhesion of chromia scales, Mater. Sci. Eng. A. 202 (1995) 1-10. doi:10.1016/09215093(95)09798-8.

[13] P. Huczkowski, S. Ertl, J. Piron-Abellan, N. Christiansen, T. Höfler, V. Shemet, L. Singheiser, W. j. Quadakkers, Effect of component thickness on lifetime and oxidation rate of chromia 
forming ferritic steels in low and high pO2 environments, Mater. High Temp. 22 (2005) 253262. doi:10.1179/mht.2005.029.

[14] A. Holt, P. Kofstad, Electrical conductivity and defect structure of $\mathrm{Cr}_{2} \mathrm{O}_{3}$. II. Reduced temperatures $\left(<1000{ }^{\circ} \mathrm{C}\right)$, Solid State Ion. 69 (1994) 137-143.

[15] W.Z. Zhu, S.C. Deevi, Opportunity of metallic interconnects for solid oxide fuel cells: a status on contact resistance, Mater. Res. Bull. 38 (2003) 957-972. doi:10.1016/S0025-5408(03)00076$\mathrm{X}$.

[16] S. Taniguchi, M. Kadowaki, H. Kawamura, T. Yasuo, Y. Akiyama, Y. Miyake, T. Saitoh, Degradation phenomena in the cathode of a solid oxide fuel cell with an alloy separator, J. Power Sources. 55 (1995) 73-79. doi:10.1016/0378-7753(94)02172-Y.

[17] J.J. Bentzen, J.V.T. Høgh, R. Barfod, A. Hagen, Chromium Poisoning of LSM/YSZ and LSCF/CGO Composite Cathodes, Fuel Cells. 9 (2009) 823-832. doi:10.1002/fuce.200800143.

[18] N. Shaigan, W. Qu, D.G. Ivey, W. Chen, A review of recent progress in coatings, surface modifications and alloy developments for solid oxide fuel cell ferritic stainless steel interconnects, J. Power Sources. 195 (2010) 1529-1542. doi:10.1016/j.jpowsour.2009.09.069.

[19] Y. Larring, T. Norby, Spinel and Perovskite Functional Layers Between Plansee Metallic Interconnect (Cr-5 wt \% Fe-1 wt \% $\left.\mathrm{Y}_{2} \mathrm{O}_{3}\right)$ and Ceramic $\left(\mathrm{La}_{0.85} \mathrm{Sr}_{0.15}\right)_{0.91} \mathrm{MnO}_{3}$ Cathode Materials for Solid Oxide Fuel Cells, J. Electrochem. Soc. 147 (2000) 3251-3256. doi:10.1149/1.1393891.

[20] H. Kurokawa, C.P. Jacobson, L.C. DeJonghe, S.J. Visco, Chromium vaporization of bare and of coated iron-chromium alloys at 1073 K, Solid State Ion. 178 (2007) 287-296. doi:10.1016/j.ssi.2006.12.010.

[21] X. Montero, F. Tietz, D. Sebold, H.P. Buchkremer, A. Ringuede, M. Cassir, A. Laresgoiti, I. Villarreal, $\mathrm{MnCo}_{1.9} \mathrm{Fe}_{0.1} \mathrm{O}_{4}$ spinel protection layer on commercial ferritic steels for interconnect applications in solid oxide fuel cells, J. Power Sources. 184 (2008) 172-179. doi:10.1016/j.jpowsour.2008.05.081.

[22] L. Chen, E.Y. Sun, J. Yamanis, N. Magdefrau, Oxidation Kinetics of $\mathrm{Mn}_{1.5} \mathrm{Co}_{1.5} \mathrm{O}_{4}$-Coated Haynes 230 and Crofer 22 APU for Solid Oxide Fuel Cell Interconnects, J. Electrochem. Soc. 157 (2010) B931-B942. doi:10.1149/1.3391820.

[23] A. Balland, P. Gannon, M. Deibert, S. Chevalier, G. Caboche, S. Fontana, Investigation of $\mathrm{La} 2 \mathrm{O} 3$ and/or (Co,Mn)3O4 deposits on Crofer22APU for the SOFC interconnect application, Surf. Coat. Technol. 203 (2009) 3291-3296. doi:10.1016/j.surfcoat.2009.04.017.

[24] B. Talic, H. Falk-Windisch, V. Venkatachalam, P.V. Hendriksen, K. Wiik, H.L. Lein, Effect of coating density on oxidation resistance and $\mathrm{Cr}$ vaporization from solid oxide fuel cell interconnects, J. Power Sources. 354 (2017) 57-67. doi:10.1016/j.jpowsour.2017.04.023. 
[25] N.J. Magdefrau, L. Chen, E.Y. Sun, M. Aindow, Effects of alloy heat treatment on oxidation kinetics and scale morphology for Crofer 22 APU, J. Power Sources. 241 (2013) 756-767. doi:10.1016/j.jpowsour.2013.03.181.

[26] S. Fontana, M. Vuksa, S. Chevalier, G. Caboche, P. Piccardo, On the Effect of Surface Treatment to Improve Oxidation Resistance and Conductivity of Metallic Interconnects for SOFC in Operating Conditions, Mater. Sci. Forum. 595-598 (2008) 753-762. doi:10.4028/www.scientific.net/MSF.595-598.753.

[27] M.M. Stack, F.H. Stott, G.C. Wood, The effect of pre-oxidation of chromia and alumina forming alloys on erosion in laboratory simulated fluidized-bed conditions, Corros. Sci. 33 (1992) 965-983. doi:10.1016/0010-938X(92)90059-C.

[28] W. Wongpromrat, G. Berthomé, V. Parry, S. Chandra-ambhorn, W. Chandra-ambhorn, C. Pascal, A. Galerie, Y. Wouters, Reduction of chromium volatilisation from stainless steel interconnector of solid oxide electrochemical devices by controlled preoxidation, Corros. Sci. 106 (2016) 172-178. doi:10.1016/j.corsci.2016.02.002.

[29] Y. Liu, Performance evaluation of several commercial alloys in a reducing environment, J. Power Sources. 179 (2008) 286-291. doi:10.1016/j.jpowsour.2007.12.067.

[30] P. Kofstad, High Temperature Corrosion, 1988.

[31] M. Palcut, L. Mikkelsen, K. Neufeld, M. Chen, R. Knibbe, P.V. Hendriksen, Corrosion stability of ferritic stainless steels for solid oxide electrolyser cell interconnects, Corros. Sci. 52 (2010) 3309-3320. doi:10.1016/j.corsci.2010.06.006.

[32] P. Huczkowski, N. Christiansen, V. Shemet, L. Niewolak, J. Piron-Abellan, L. Singheiser, W.J. Quadakkers, Growth Mechanisms and Electrical Conductivity of Oxide Scales on Ferritic Steels Proposed as Interconnect Materials for SOFC's, Fuel Cells. 6 (2006) 93-99. doi:10.1002/fuce.200500110.

[33] S. Fontana, S. Chevalier, G. Caboche, Metallic Interconnects for Solid Oxide Fuel Cell: Performance of Reactive Element Oxide Coating During 10, 20 and 30 Months Exposure, Oxid. Met. 78 (2012) 307-328. doi:10.1007/s11085-012-9308-4.

[34] S. Canovic, J. Froitzheim, R. Sachitanand, M. Nikumaa, M. Halvarsson, L.-G. Johansson, J.-E. Svensson, Oxidation of Co- and Ce-nanocoated FeCr steels: A microstructural investigation, Surf. Coat. Technol. 215 (2013) 62-74. doi:10.1016/j.surfcoat.2012.08.096.

[35] M.P. Phaniraj, D.-I. Kim, Y.W. Cho, Effect of grain boundary characteristics on the oxidation behavior of ferritic stainless steel, Corros. Sci. 53 (2011) 4124-4130. doi:10.1016/j.corsci.2011.08.020.

[36] I.-H. Jung, Critical evaluation and thermodynamic modeling of the $\mathrm{Mn}-\mathrm{Cr}-\mathrm{O}$ system for the oxidation of SOFC interconnect, Solid State Ion. 177 (2006) 765-777. doi:10.1016/j.ssi.2006.01.012. 
[37] M.G.C. Cox, B. McEnaney, V.D. Scott, Kinetics of initial oxide growth on Fe-Cr alloys and the role of vacancies in film breakdown, Philos Mag. 31 (1975) 331-338.

[38] R.E. Lobnig, H.P. Schmidt, K. Hennesen, H.J. Grabke, Diffusion of cations in chromia layers grown on iron-base alloys, Oxid. Met. 37 (1992) 81-93.

[39] F.H. Stott, F.I. Wei, C.A. Enahoro, The influence of manganese on the High-temperature oxidation of iron-chromium alloys, Mater. Corros. 40 (1989) 198-205. doi:10.1002/maco.19890400403.

[40] J. Zhu, L.M.F. Diaz, G.R. Holcomb, P.D. Jablonski, C.J. Cowen, D.E. Laughlin, D. Alman, S. Sridhar, On the Relation Between Oxide Ridge Evolution and Alloy Surface Grain Boundary Disorientation in Fe-22 wt \% Cr Alloys, J. Electrochem. Soc. 157 (2010) B655-B664. doi:10.1149/1.3308571.

[41] C. Thorning, S. Sridhar, Grain boundary ridge formation during initial high temperature oxidation of Mn/Al TRIP steel, Philos. Mag. 87 (2007) 3479-3499. doi:10.1080/14786430701324139.

[42] H. Mehrer, Diffusion in solids: fundamentals, methods, materials, diffusion-controlled processes, Springer Science \& Business Media, 2007.

[43] J. Gilewicz-Wolter, J. Dudała, Z. Żurek, M. Homa, J. Lis, M. Wolter, Diffusion of chromium, manganese, and iron in $\mathrm{MnCr}_{2} \mathrm{O}_{4}$ spinel, J. Phase Equilibria Diffus. 26 (2005) 561-564. doi:10.1007/s11669-005-0051-2.

[44] D.J. Young, High temperature oxidation and corrosion of metals, Elsevier, 2008.

[45] M. Schütze, Deformation and cracking behavior of protective oxide scales on heat-resistant steels under tensile strain, Oxid. Met. 24 (1985) 199-232. doi:10.1007/BF00664232.

[46] P. Kofstad, Defects and transport properties of metal oxides, Oxid. Met. 44 (1995) 3-27. doi:10.1007/BF01046721.

[47] S.C. Tsai, A.M. Huntz, C. Dolin, Growth mechanism of Cr2O3 scales: oxygen and chromium diffusion, oxidation kinetics and effect of yttrium, Mater. Sci. Eng. A. 212 (1996) 6-13. doi:10.1016/0921-5093(96)10173-8.

[48] L. Niewolak, D.J. Young, H. Hattendorf, L. Singheiser, W.J. Quadakkers, Mechanisms of Oxide Scale Formation on Ferritic Interconnect Steel in Simulated Low and High pO2 Service Environments of Solid Oxide Fuel Cells, Oxid. Met. 82 (2014) 123-143. doi:10.1007/s11085014-9481-8.

[49] T. Brylewski, M. Nanko, T. Maruyama, K. Przybylski, Application of Fe-16Cr ferritic alloy to interconnector for a solid oxide fuel cell, Solid State Ion. 143 (2001) 131-150. doi:10.1016/S0167-2738(01)00863-3.

[50] T. Norby, Protonic defects in oxides and their possible role in high temperature oxidation, J. Phys. IV. 03 (1993) C9-99-C9-106. doi:10.1051/jp4:1993907. 
[51] T. Norby, M. Widerøe, R. Glöckner, Y. Larring, Hydrogen in oxides, Dalton Trans. 0 (2004) 3012-3018. doi:10.1039/B403011G.

[52] L. Latu-Romain, S. Mathieu, M. Vilasi, G. Renou, S. Coindeau, A. Galerie, Y. Wouters, The Role of Oxygen Partial Pressure on the Nature of the Oxide Scale on a NiCr Model Alloy, Oxid. Met. (2016) 1-13. doi:10.1007/s11085-016-9670-8.

[53] L. Latu-Romain, Y. Madi, S. Mathieu, F. Robaut, J.-P. Petit, Y. Wouters, Advanced STEM/EDX investigation on an oxide scale thermally grown on a high-chromium iron-nickel alloy under very low oxygen partial pressure, Corros. Sci. 101 (2015) 193-200. doi:10.1016/j.corsci.2015.09.021.

[54] M.K. Hossain, Effects of alloy microstructure on the high temperature oxidation of an $\mathrm{Fe}-10 \%$ Cr alloy, Corros. Sci. 19 (1979) 1031-1045. doi:10.1016/S0010-938X(79)80093-1.

[55] J.J. Barnes, J.G. Goedjen, D.A. Shores, A Model for stress generation and relief in oxideMetal systems during a temperature change, Oxid. Met. 32 (1989) 449-469.

[56] Y.-T. Chiu, C.-K. Lin, J.-C. Wu, High-temperature tensile and creep properties of a ferritic stainless steel for interconnect in solid oxide fuel cell, J. Power Sources. 196 (2011) 2005-2012. doi:10.1016/j.jpowsour.2010.09.083.

[57] C.R. Barrett, J.L. Lytton, O.D. Sherby, Effect of grain size and annealing treatment on steadystate creep of copper, Trans AIME. 239 (1967).

[58] B. Hua, Y. Kong, W. Zhang, J. Pu, B. Chi, L. Jian, The effect of Mn on the oxidation behavior and electrical conductivity of $\mathrm{Fe}-17 \mathrm{Cr}$ alloys in solid oxide fuel cell cathode atmosphere, $\mathrm{J}$. Power Sources. 196 (2011) 7627-7638. doi:10.1016/j.jpowsour.2011.05.007.

[59] A.L. Marasco, D.J. Young, The oxidation of Iron-Chromium-Manganese alloys at $900^{\circ} \mathrm{C}$, Oxid. Met. 36 (1991) 157-174. doi:10.1007/BF00938460.

[60] B. Tveten, G. Hultquist, T. Norby, Hydrogen in Chromium: Influence on the High-Temperature Oxidation Kinetics in O2, Oxide-Growth Mechanisms, and Scale Adherence, Oxid. Met. 51 (1999) 221-233. doi:10.1023/A:1018866505708.

\section{Figures}




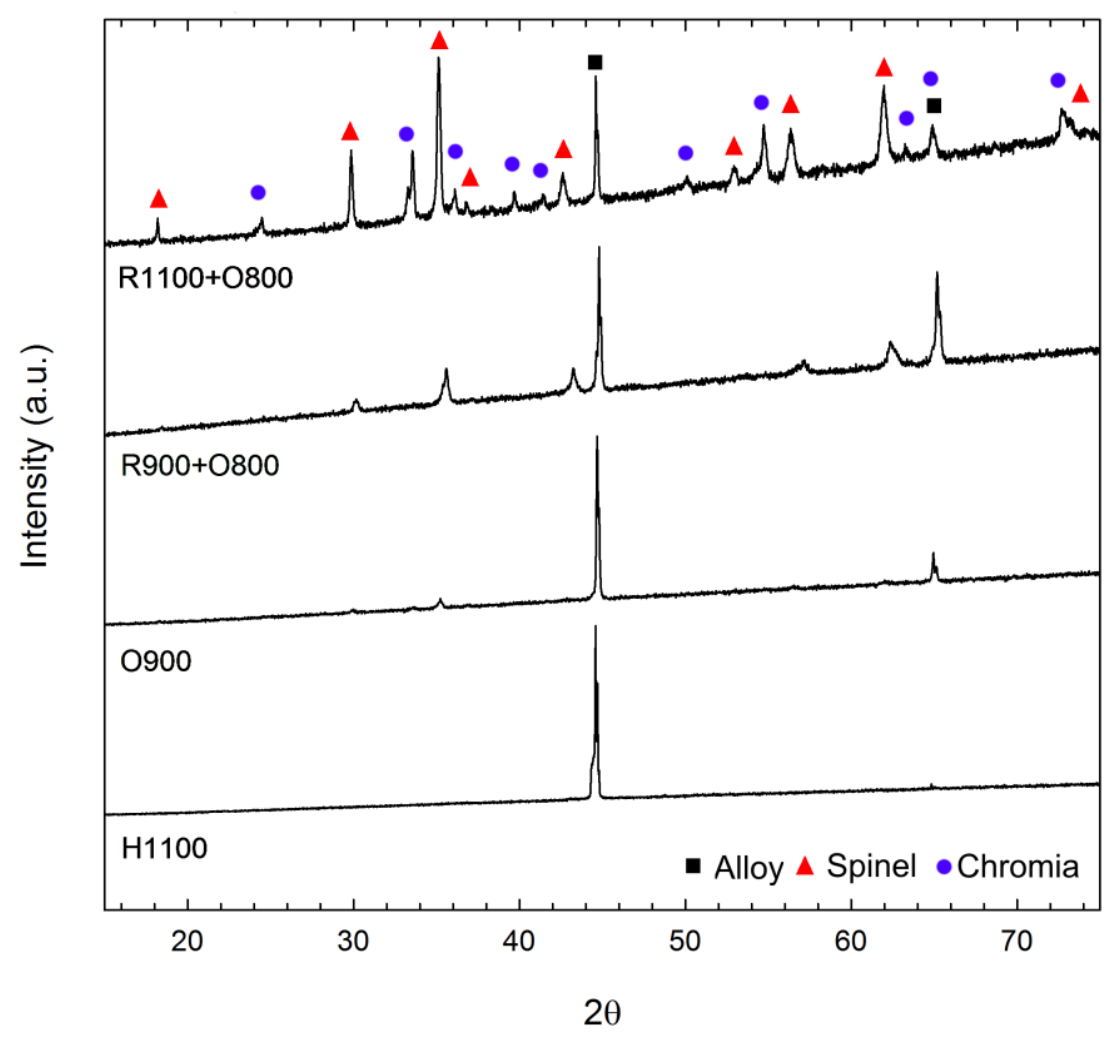

Figure 1. X-ray diffractograms of Crofer 22 APU after pre-oxidation heat treatment. Alloy $=$ PDF 654664, Spinel $=$ PDF 75-1614, Chromia $=$ PDF 38-1479.
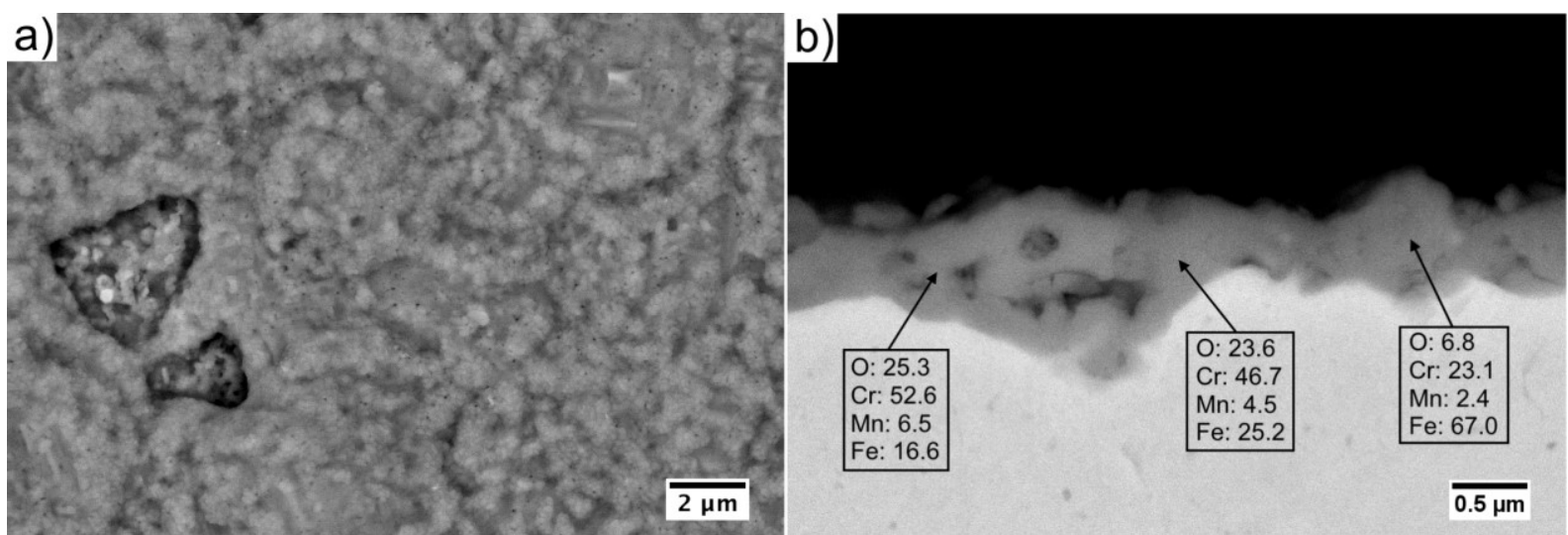

Figure 2. SEM BSE micrographs of R900+O800 after pre-oxidation heat treatment. (a) surface, (b) cross section and EDX point analysis results (in wt.\%). 


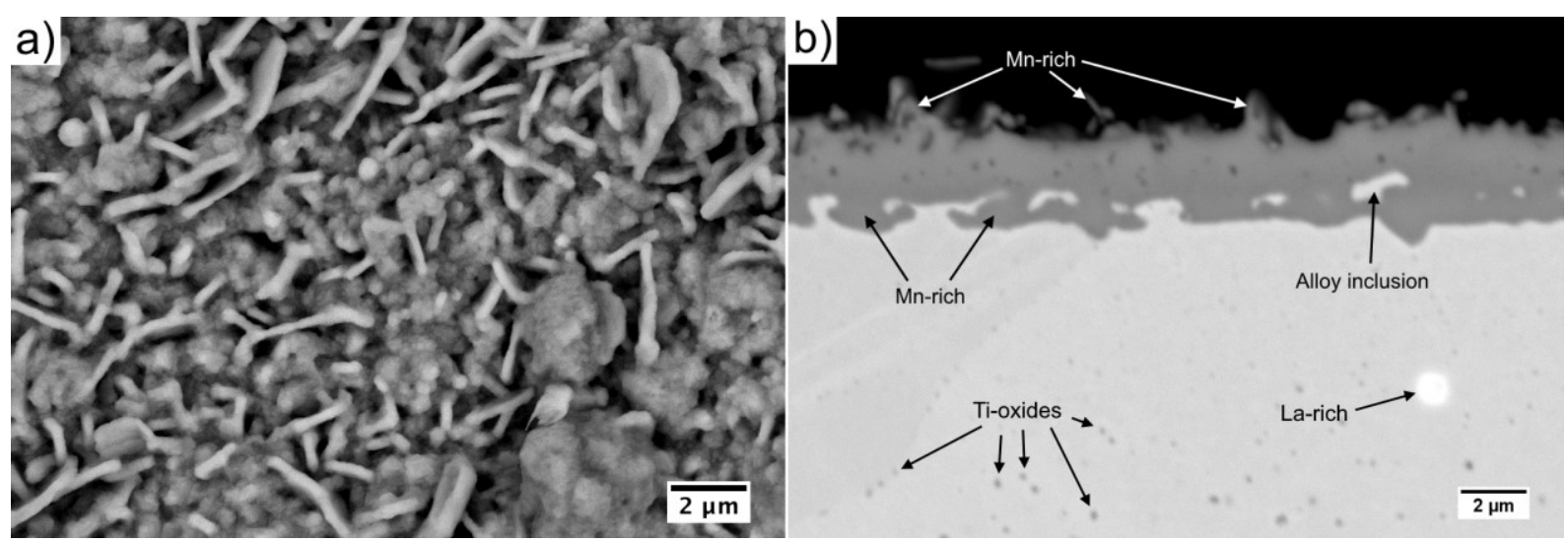

Figure 3. SEM BSE micrographs of R1100+O800 after pre-oxidation heat treatment. (a) surface, (b) cross section.
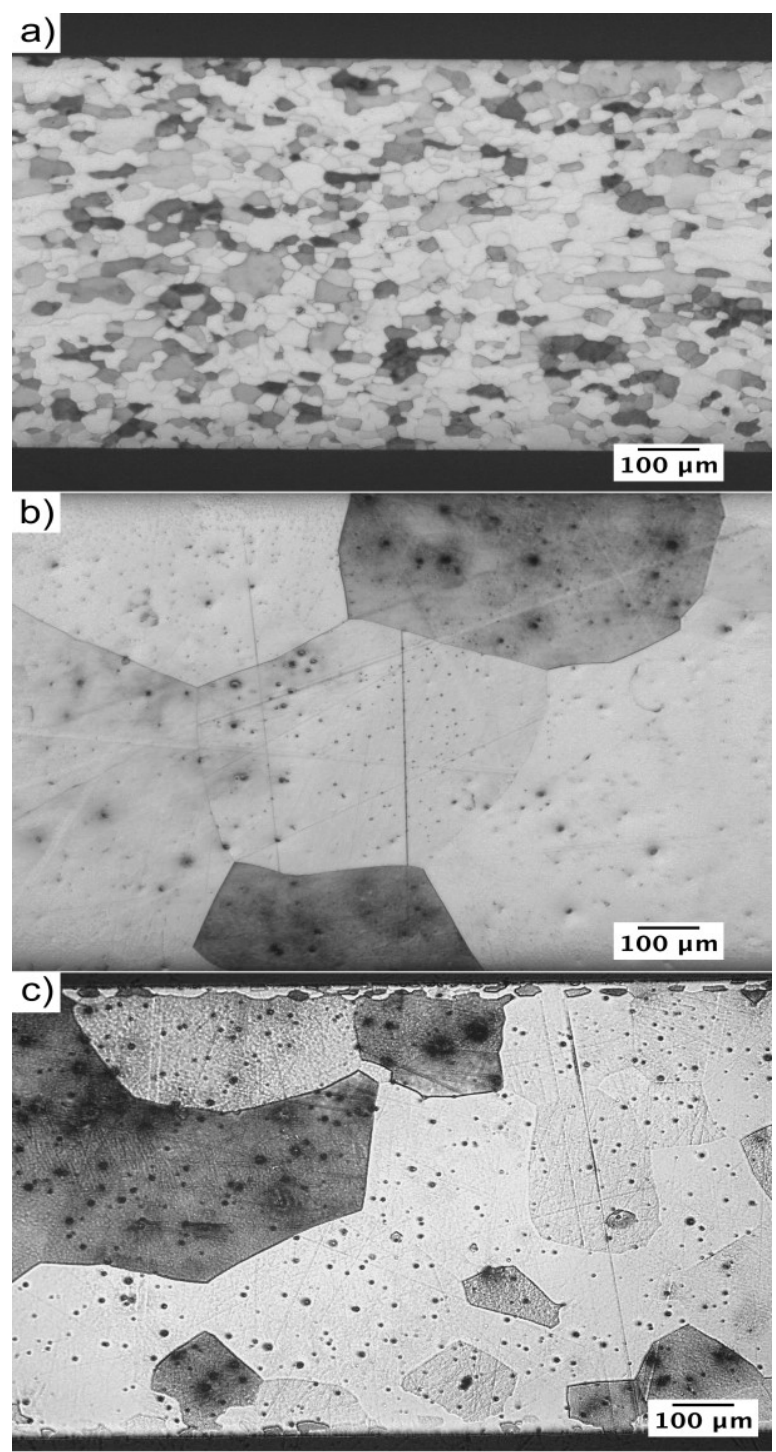

Figure 4. Optical micrographs of etched cross sections. (a) as-received Crofer 22 APU, (b) after H1100 heat treatment, (c) after R1100+O800 pre-oxidation heat treatment. 
a)

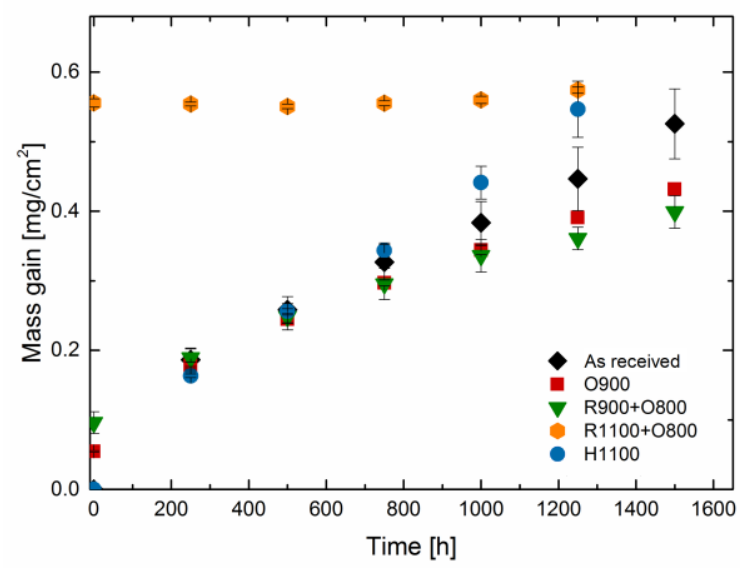

b)

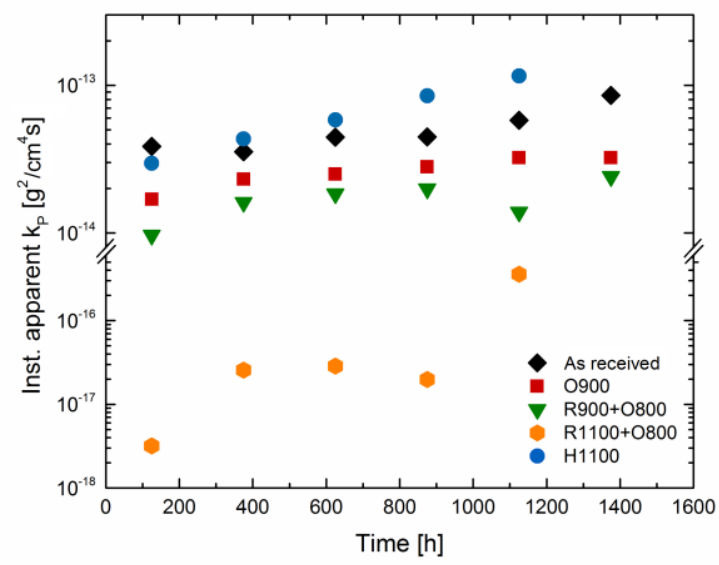

Figure 5. Mass change of Crofer 22 APU during cyclic oxidation in air at $800{ }^{\circ} \mathrm{C}$. Each point is the average of 3-5 samples and error bar shows the standard deviation. a) Mass gain versus time. Mass gain during pre-oxidation is added to $\mathrm{t}=0 \mathrm{~h}$. b) Instantaneous apparent parabolic rate versus time. Note the break in the y-axis.

a)

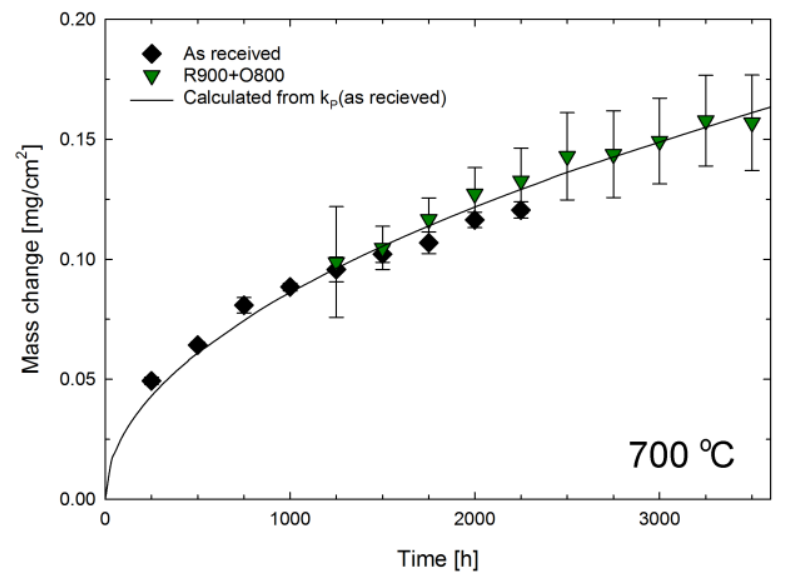

b)

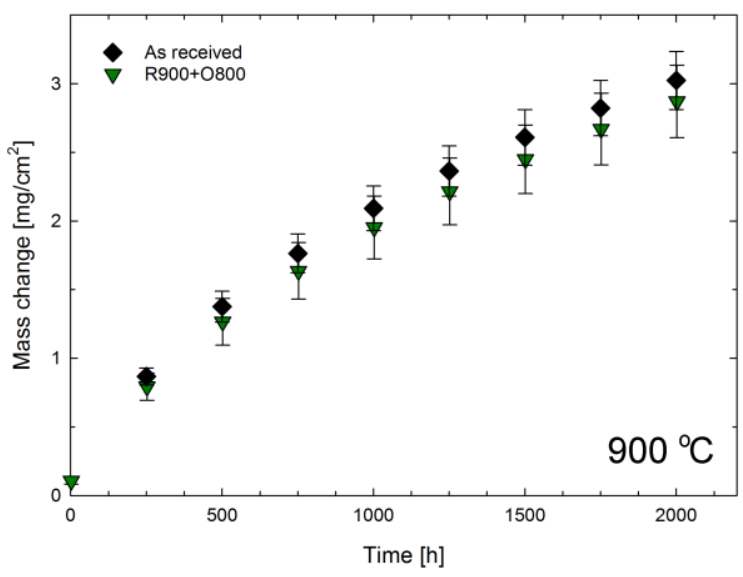

Figure 6. Mass change during cyclic oxidation in air. (a) at $700{ }^{\circ} \mathrm{C}$, showing also the parabolic fit to the mass change of the as-received sample, (b) at $900{ }^{\circ} \mathrm{C}$. 


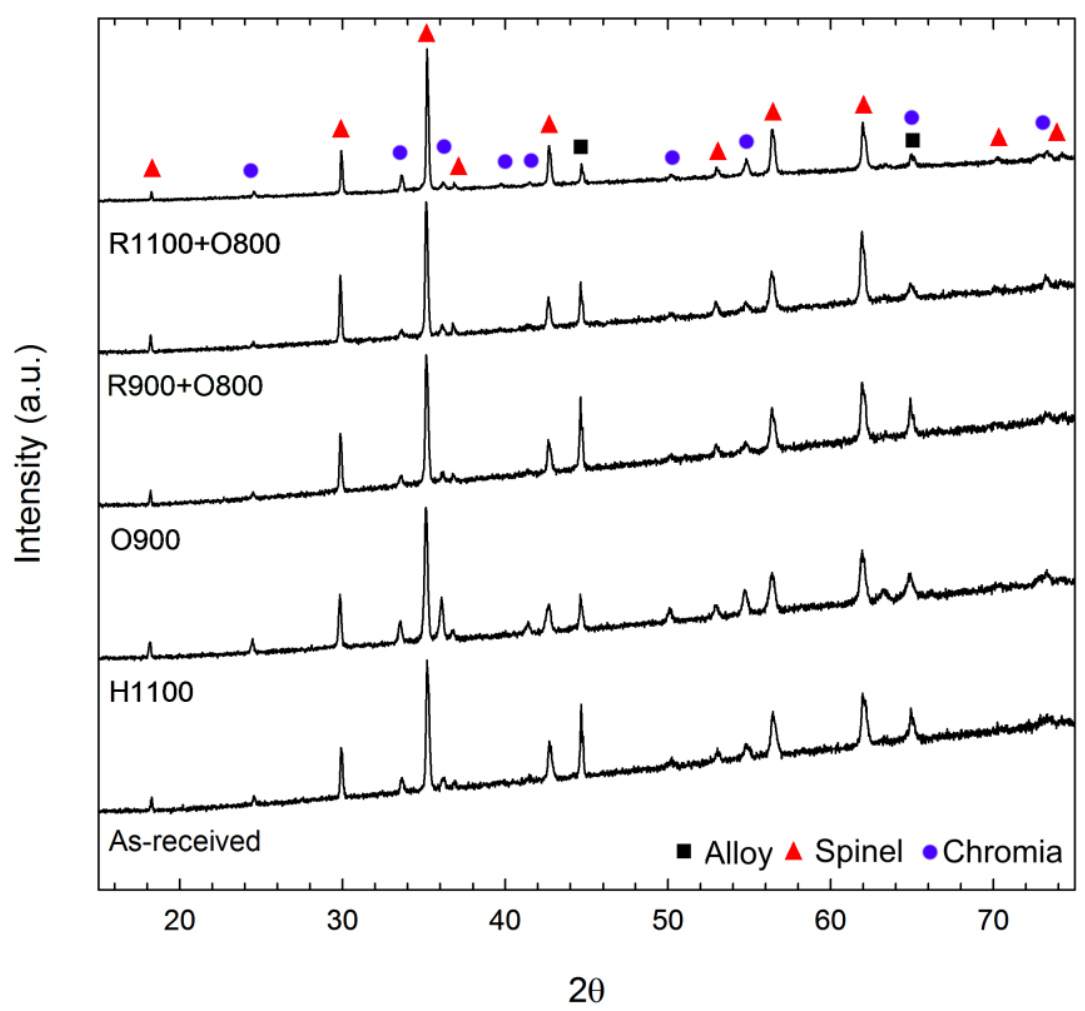

Figure 7. X-ray diffractograms of Crofer 22 APU after $1000 \mathrm{~h}$ oxidation in air at $800^{\circ} \mathrm{C}$. Alloy $=\mathrm{PDF}$ 65-4664, Spinel = PDF 75-1614, Chromia = PDF 38-1479.
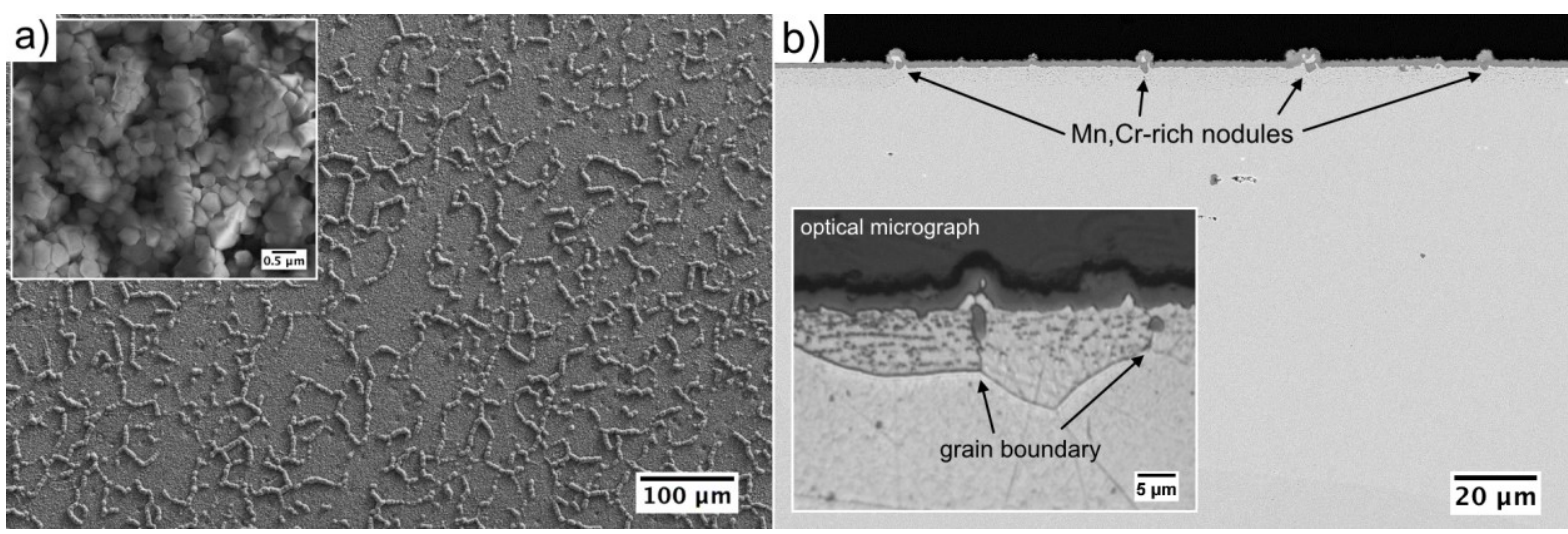

Figure 8. Micrographs of as-received Crofer $22 \mathrm{APU}$ after $1000 \mathrm{~h}$ oxidation at $800{ }^{\circ} \mathrm{C}$ in air. (a) SEMSE surface, (b) SEM-BSE of cross section and (insert) optical micrograph of etched cross section. 


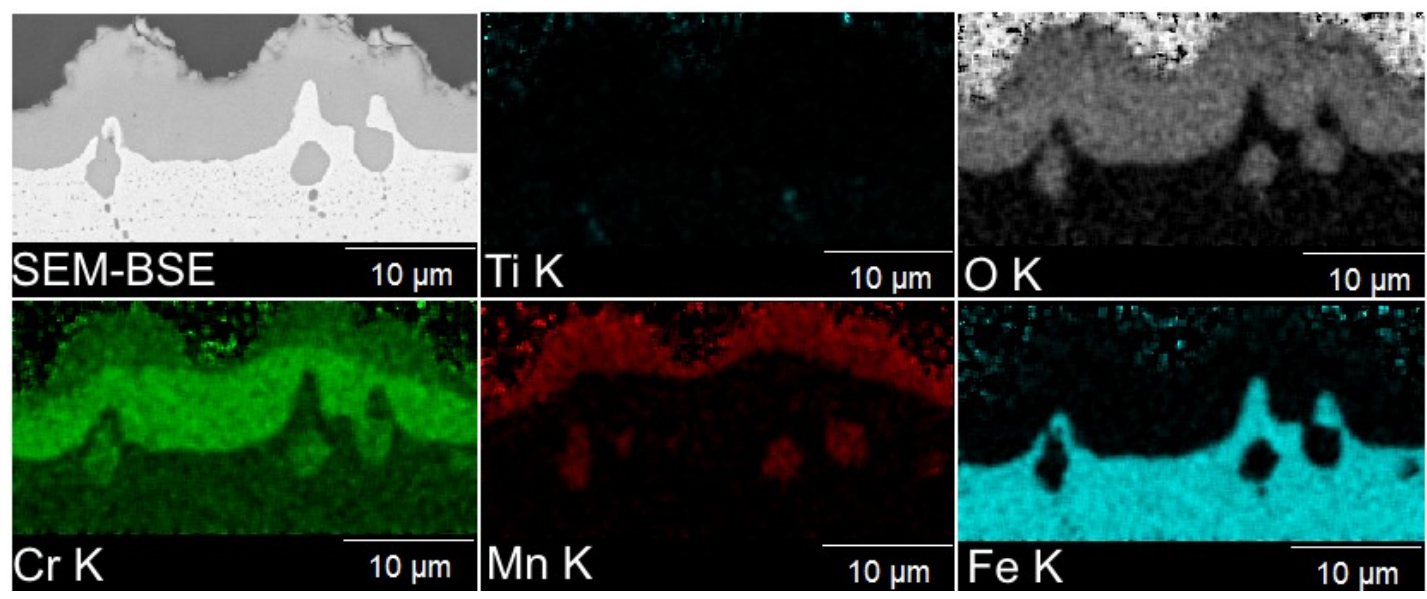

Figure 9. Cross-section SEM-BSE micrograph and EDX maps of as-received sample after $1000 \mathrm{~h}$ oxidation at $800^{\circ} \mathrm{C}$ in air.
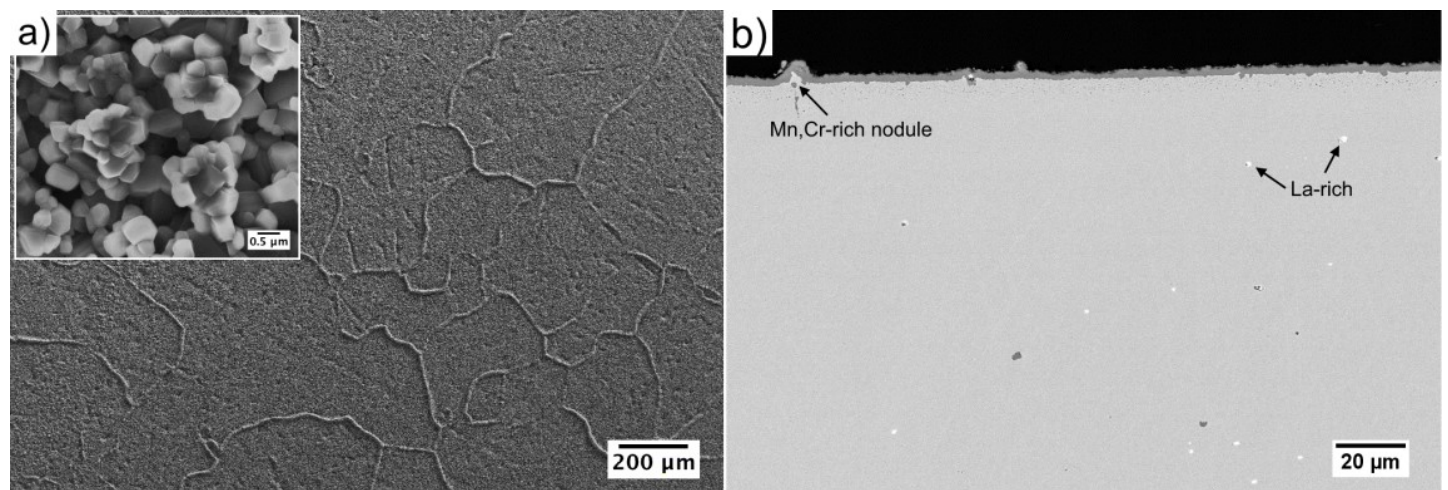

Figure 10. Surface (a) and cross sectional (b) SEM micrographs of H1100 sample after $1000 \mathrm{~h}$ oxidation at $800{ }^{\circ} \mathrm{C}$ in air.
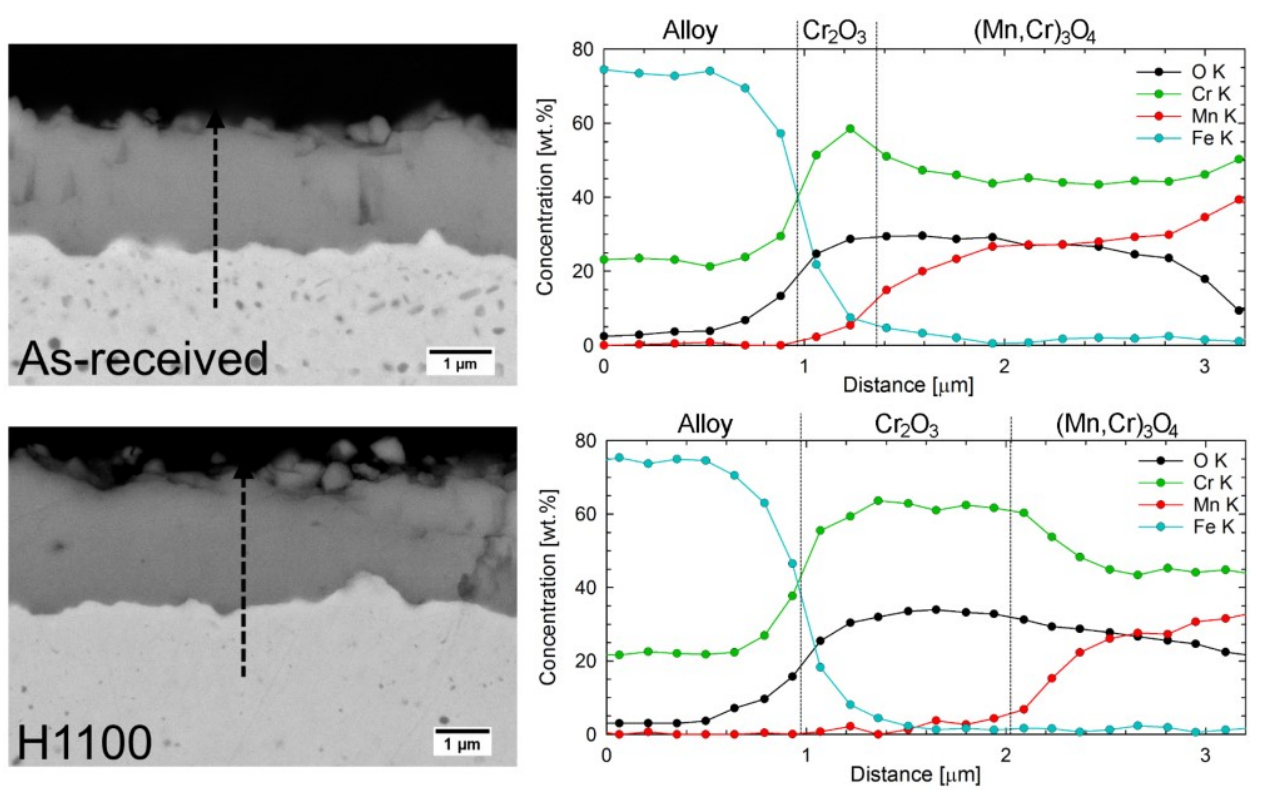

Figure 11. Cross sectional SEM-EDX images and EDX compositional linescans of the as-received (top) and $\mathrm{H} 1100$ (bottom) samples after $1000 \mathrm{~h}$ oxidation at $800{ }^{\circ} \mathrm{C}$ in air. 

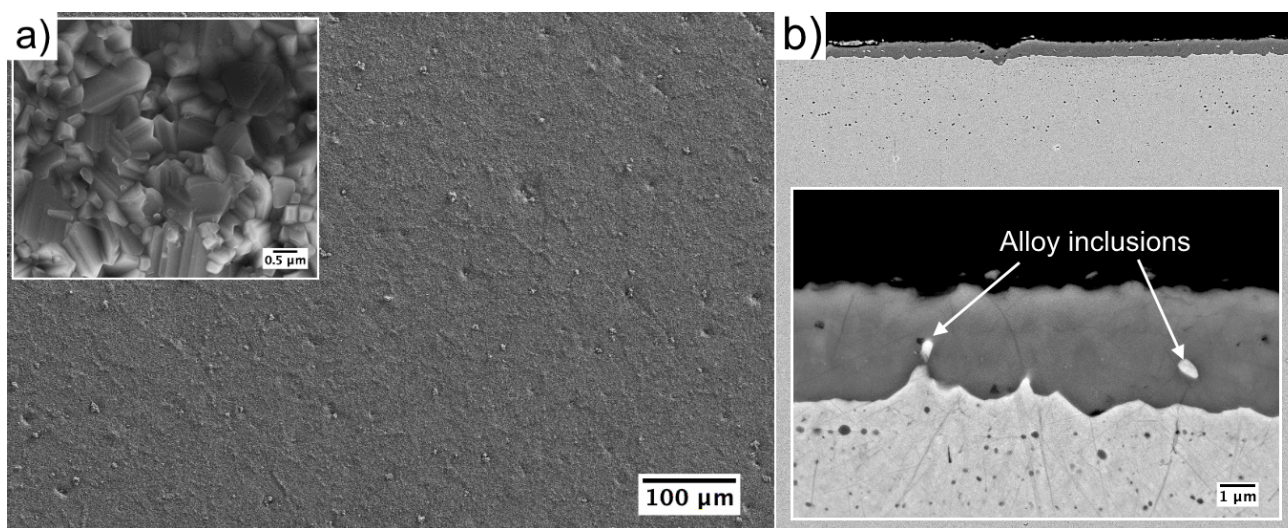

$\overline{20 \mu \mathrm{m}}$

Figure 12. Surface (a) and cross sectional (b) SEM micrographs of R1100+O800 sample after $1000 \mathrm{~h}$ oxidation at $800{ }^{\circ} \mathrm{C}$ in air

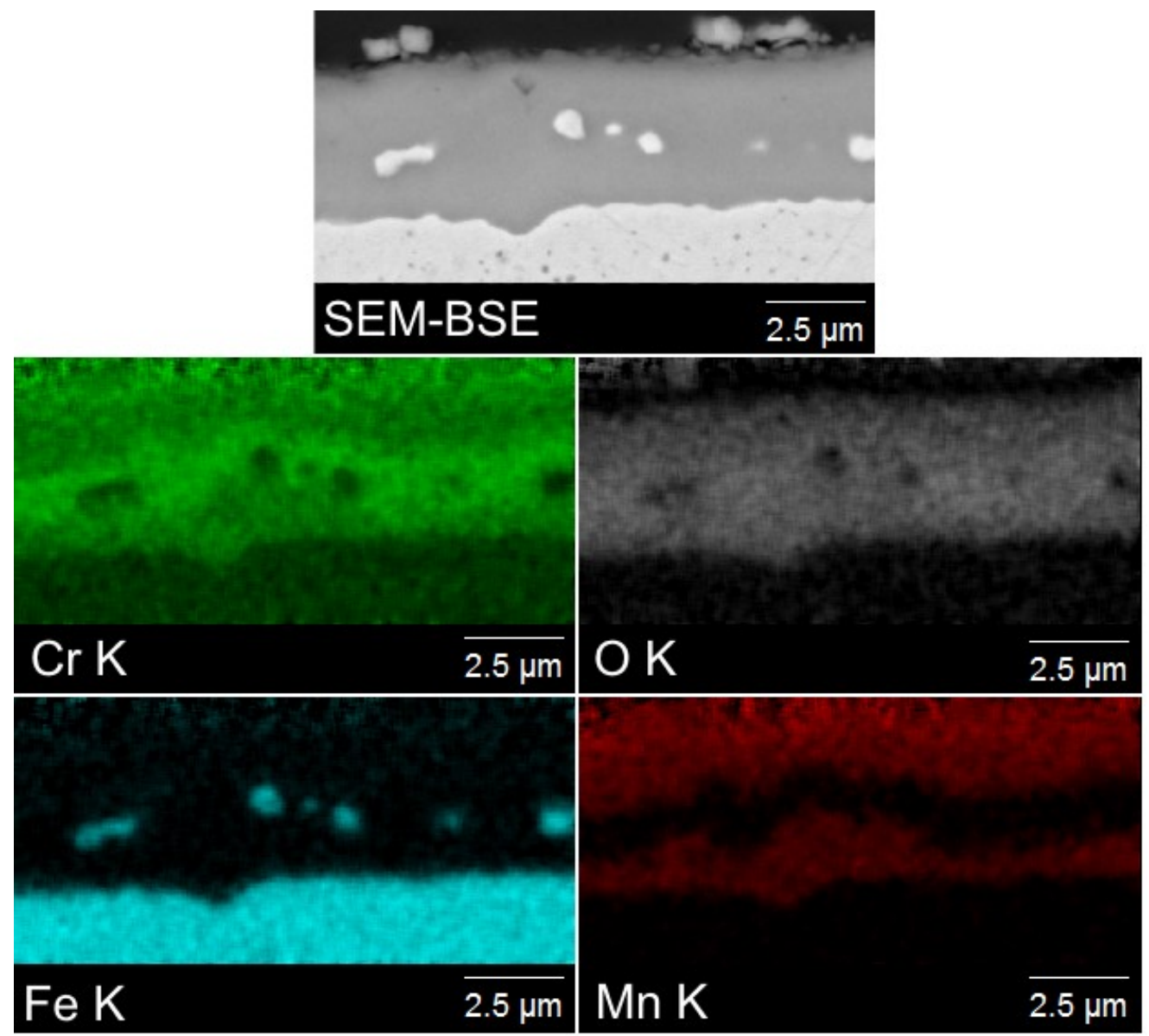

Figure 13. SEM-BSE micrograph and EDX maps of R1100+O800 sample after $1000 \mathrm{~h}$ oxidation at $800{ }^{\circ} \mathrm{C}$ in air. 


\title{
Supplementary material
}

\section{Effect of pre-oxidation on the oxidation resistance of Crofer 22 APU}

\author{
Belma Talic ${ }^{\mathrm{a}, \mathrm{b}}$, Sebastian Molin ${ }^{\mathrm{b}}$, Peter Vang Hendriksen ${ }^{\mathrm{b}}$, Hilde Lea Lein ${ }^{\mathrm{a}}$ \\ a Department of Materials Science and Engineering, Norwegian University of Science and Technology, \\ Norway \\ ${ }^{b}$ Department of Energy Conversion and Storage, Technical University of Denmark, Risø Campus, Denmark
}

The general rate equation for oxidation may be expressed as [1]:

$$
m^{n}=k_{n} t+C
$$

where $\mathrm{m}$ is the mass gain, $\mathrm{k}_{\mathrm{n}}$ is the rate constant, $t$ is the time, and $\mathrm{C}$ is an integration constant. The exponent $\mathrm{n}$ has values of 1, 2 and 3 for linear, parabolic and cubic oxidation kinetics, respectively. Taking the logarithm of Equation S1 gives:

$$
\log m=\frac{1}{n} \log t+C
$$

Thus, a double-logarithmic plot of the mass gain versus time provides a method for evaluating the oxidation rate law.

Double-logarithmic plots for all samples oxidized in air at $800{ }^{\circ} \mathrm{C}$ are shown in Figures S1-S3. In case of the pre-oxidized samples, the mass gain during oxidation was included in the evaluation $\left(0.055 \mathrm{mg} / \mathrm{cm}^{2}\right.$ for $\mathrm{O} 900,0.096 \mathrm{mg} / \mathrm{cm}^{2}$ for $\mathrm{R} 900+\mathrm{O} 800$, and $0.556 \mathrm{mg} / \mathrm{cm}^{2}$ for $\left.\mathrm{R} 1100+\mathrm{O} 800\right)$ and it was adjusted for the "equivalent age" of the pre-oxidation. The equivalent age is taken as the time the as-received Crofer $22 \mathrm{APU}$ was oxidized in air at $800{ }^{\circ} \mathrm{C}$ before acquiring the same mass gain as during the pre-oxidation heat treatment. For example, the mass gain after R $1100+800$ pre-oxidation was 0.556 $\mathrm{mg} / \mathrm{cm}^{2}$, and as-received Crofer $22 \mathrm{APU}$ was oxidized ca. $1650 \mathrm{~h}$ at $800{ }^{\circ} \mathrm{C}$ before gaining the same mass. Thus, the equivalent age of the $\mathrm{R} 1100+\mathrm{O} 800$ pre-oxidation is $1650 \mathrm{~h}$. By making this adjustment, the existing oxide scale on pre-oxidized samples is accounted for when comparing the oxidation results.

The exponent $\mathrm{n}$, determined as the inverse slope of the linear fit to the plots in Figures S1-S3, is listed in Table S1. In case of the R1100+O800 sample, only the three last points were used in the fitting. 


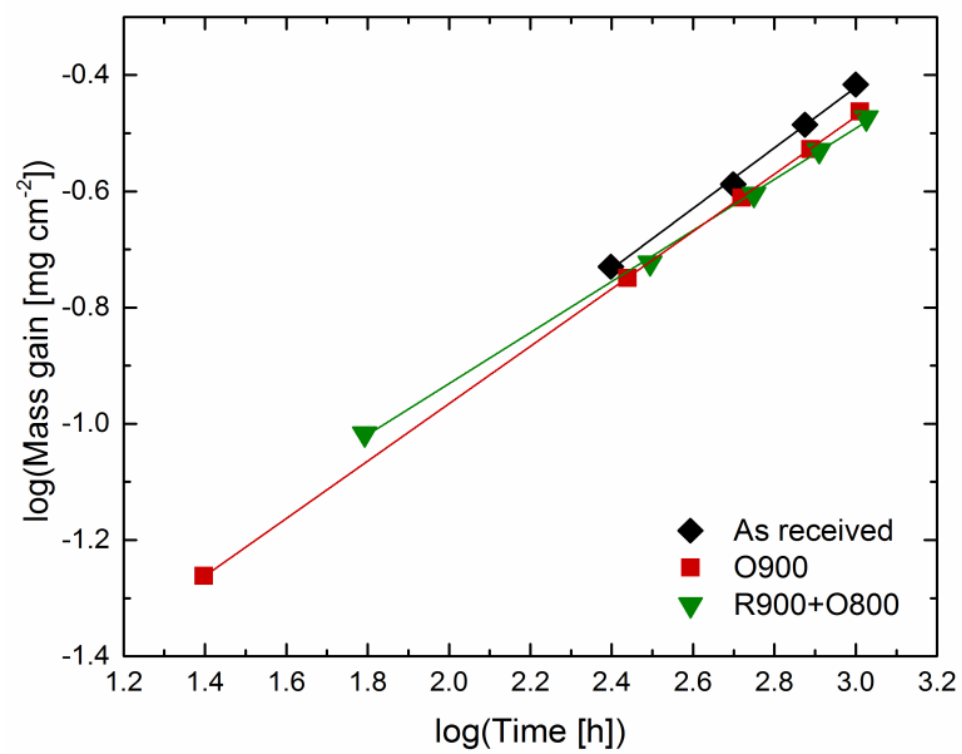

Figure S1. Double-logartihmic plot for oxidation of as-received, O900 and R900+O800 samples.

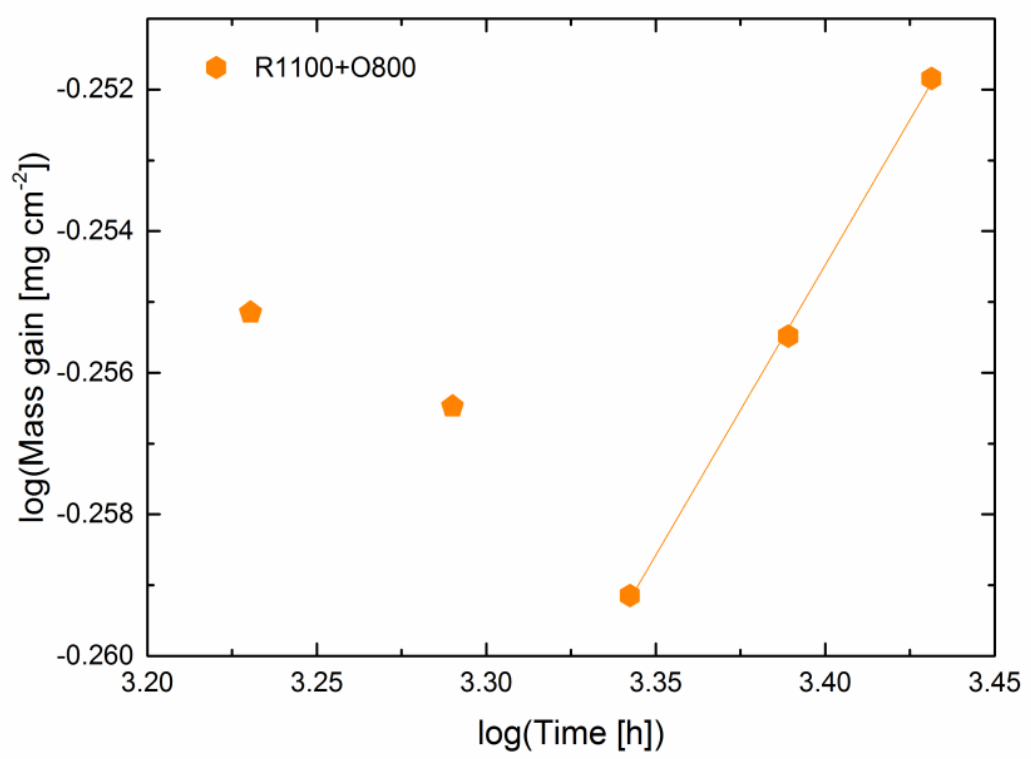

Figure S2. Double-logartihmic plot for oxidation of R1100+O800 sample. 


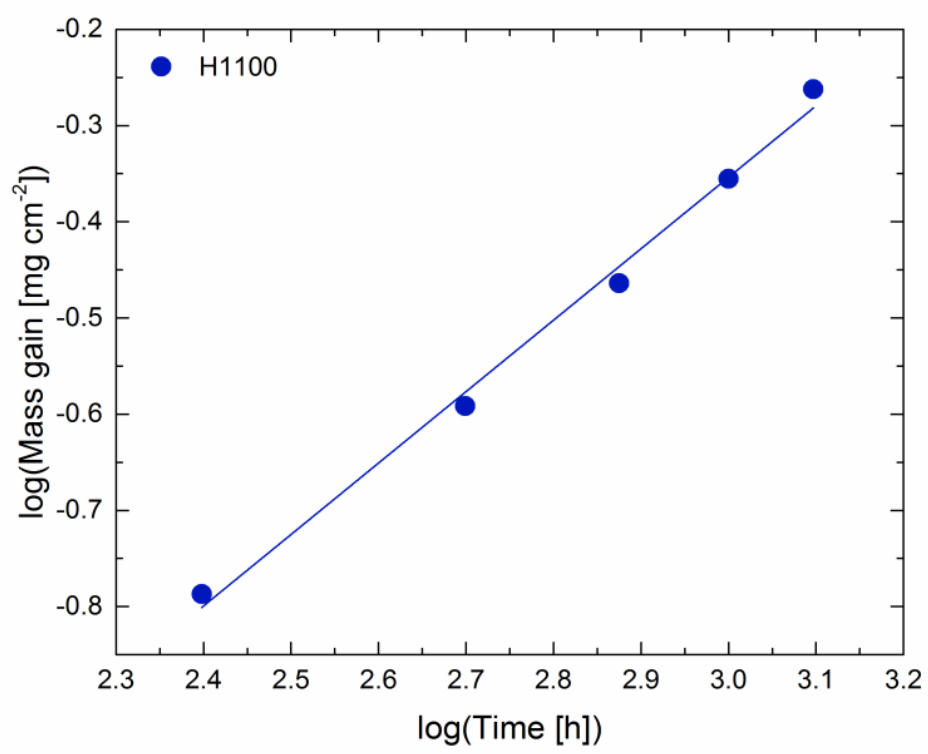

Figure S3. Double-logartihmic plot for oxidation of H1100 sample.

Table S1. Exponent n (Eq. S1) for oxidation at $800^{\circ} \mathrm{C}$ in air, determined from double-logarithmic plots in Figures S1-S3.

\begin{tabular}{ll}
\hline Sample & $\mathrm{n}$ \\
\hline As-received & 1.9 \\
O900 & 2.0 \\
R900+O800 & 2.3 \\
R1100+O800 & 12.5 \\
H1100 & 1.4
\end{tabular}

Polished coupons of Crofer 22 APU were oxidized in $\mathrm{N}_{2}-9 \% \mathrm{H}_{2}-1 \% \mathrm{H}_{2} \mathrm{O}$ at $1100{ }^{\circ} \mathrm{C}$ for $5 \mathrm{~h}$ and then in air at $800{ }^{\circ} \mathrm{C}$ for $5 \mathrm{~h}(\mathrm{R} 1100+\mathrm{O} 800)$. The oxide scale was subsequently removed by grinding and polishing. Figure $\mathrm{S} 4$ shows the mass change of these samples measured during oxidation at $800{ }^{\circ} \mathrm{C}$ in air. The results for the as-received sample are shown for comparison. 


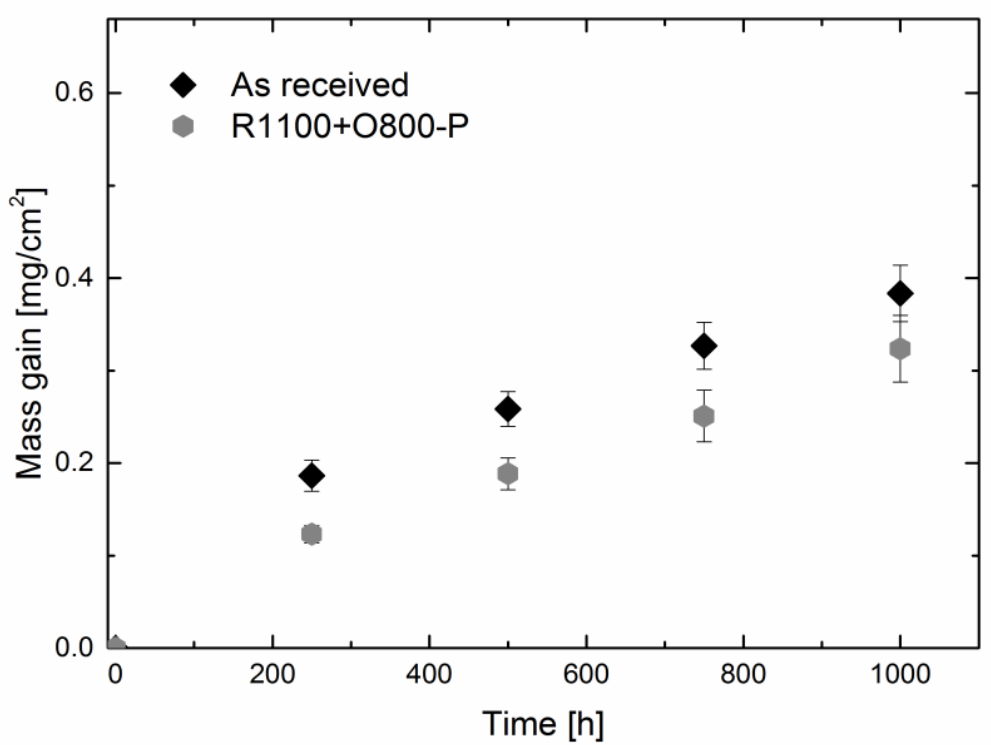

FIGURE S4. Mass change measured during oxidation at $800{ }^{\circ} \mathrm{C}$ in air. Average of three samples with error bars showing standard deviation.

Figure S5 presents the mass change re-calculated to include the mass gain during pre-oxidation with the curves shifted along the $\mathrm{x}$-axis to adjust for the "equivalent age" of the sample. The "equivalent age" is taken as the time the as-received Crofer 22 APU would have to be oxidized in air at the $800{ }^{\circ} \mathrm{C}$ before acquiring the same mass gain as during the pre-oxidation heat treatment

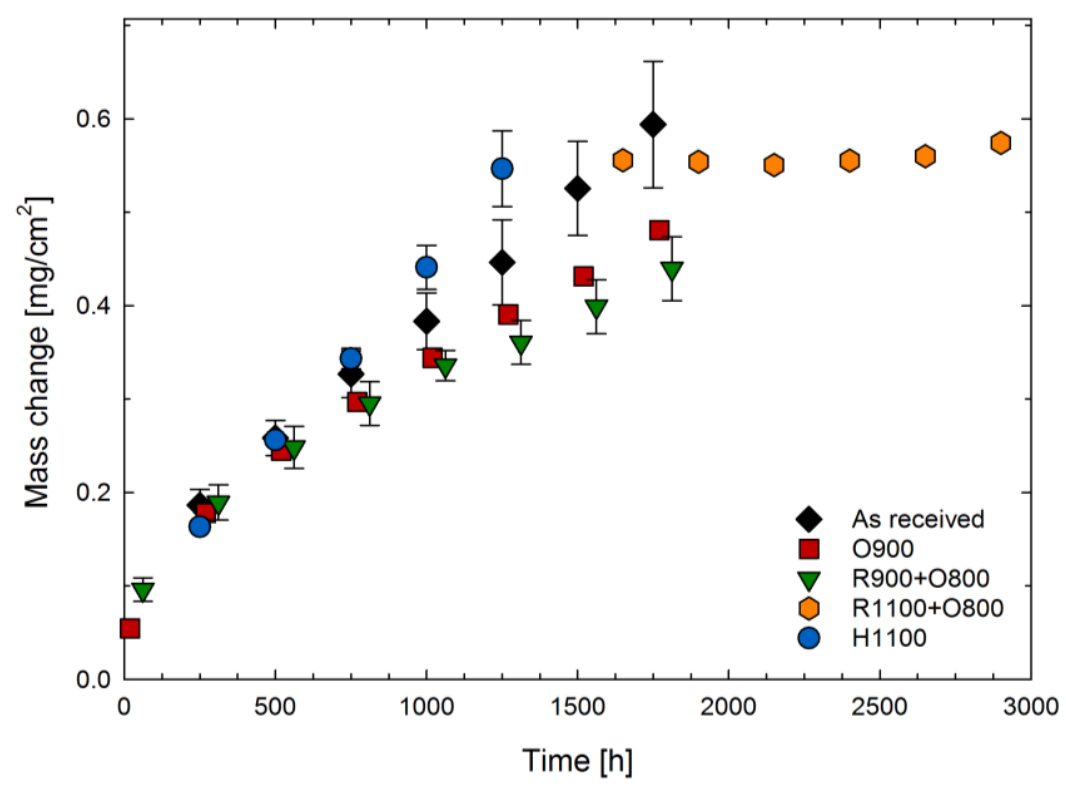

Figure S5. Mass change of Crofer 22 APU during oxidation in air at $800^{\circ} \mathrm{C}$, including the mass change during pre-oxidation and a curve shift along the $\mathrm{x}$-axis to account for the equivalent age.

\section{Reference}

[1] P. Kofstad, High Temperature Corrosion, 1988. 